\title{
IMPACT OF MANAGEMENT INTERVENTIONNS: ON THE PERFORMANCE OF
} FIVE IRRIGATION SCHEMES IN SRI LANKA

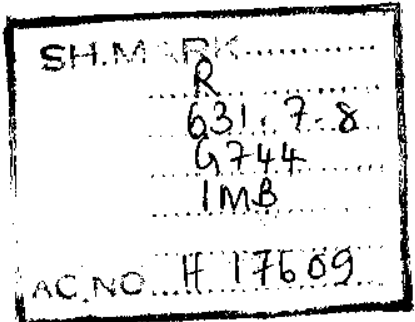

\author{
K.A.U.S. Imbulana \\ and \\ Douglas J. Merrey
}

H $17609 \quad C_{1}$

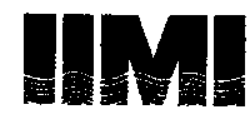

INTERNATIONAL IRRIGATION MANAGEMENT INSTITUTE 
Imbulana, K.A.U.S.; and Merrey, D.J. Impact of management interventions on the performance of five irrigation schemes in Sri Lanka. Colombo, Sri Lanka: International Irrigation Management Institute (IIMI). xiii, 76p. (IIMI working paper no. 35).

/irrigation programs / performance evaluation /irrigation management / intervention / irrigation systems /monitoring / performance indexes:/history / farmers' associations / farmer participation / farmer-agency interactions / communication / organizations / water potential / rice / crop yield / water supply / land productivity / rain / data collection / Sri Lanka / Dewahuwa / Mapakada / Parakrama Samudra / Rajangane / Ridiyagama /

DDC: 631.7

ISBN: $92-9090-318-X$

IIMI's Working Paper series is intended to stimulate discussion among people interested in aspects of irrigation management. These papers make available the results of recent or ongoing research, and the informed opinions of IIMI staff members and collaborators, as early as possible. The views expressed are, therefore, those of the authors and do not (at this stage) necessarily represent the consensus of IIMI or its partners. IIMI will welcome comments on this paper, which should be sent either to IIMI or to the authors at the following address:

Information Office

International Irrigation Management Institute

P.O. Box 2075

Colombo

Sri Lanka

(C) IIMI, 1995

All rights reserved. 


\section{Contents}

Figures

vii

Tables

ix

Preface

$x \mathrm{i}$

Executive Summary

xiii

$1 . \quad$ Introduction

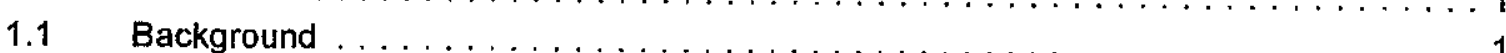

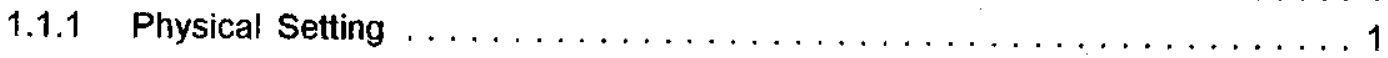

1.1.2 Historical Development of Irrigation in Sri Lanka $\ldots \ldots \ldots \ldots \ldots \ldots \ldots$

1.1 .3 Present Status of Irrigation Performance $\ldots \ldots \ldots \ldots \ldots \ldots \ldots \ldots \ldots$

1.2 Research Objectives and Research Questions $\ldots \ldots \ldots \ldots \ldots \ldots \ldots$

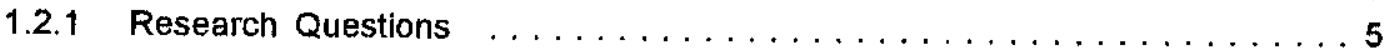

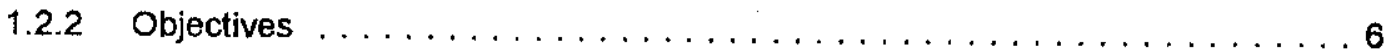

$1.3 \quad$ Research Approach $\ldots \ldots \ldots \ldots \ldots \ldots \ldots \ldots \ldots \ldots \ldots \ldots$

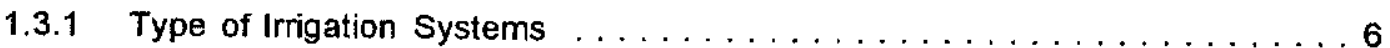

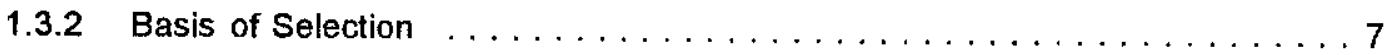

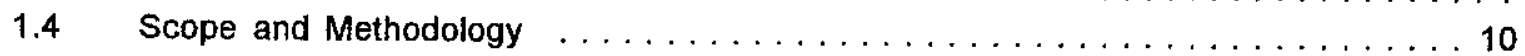

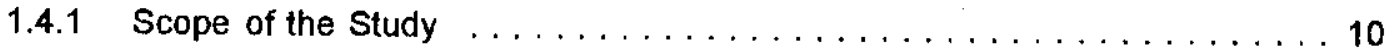

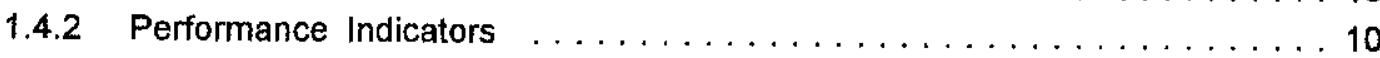

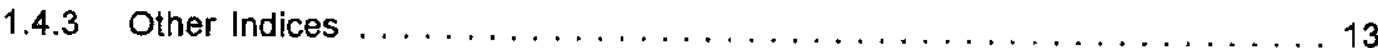

2. Irrigation Systems and Their Management $\ldots \ldots \ldots \ldots \ldots \ldots \ldots \ldots \ldots \ldots \ldots$

2.1 State Organizations Involved in Irrigation Management $\ldots \ldots \ldots \ldots \ldots \ldots \ldots \ldots \ldots$

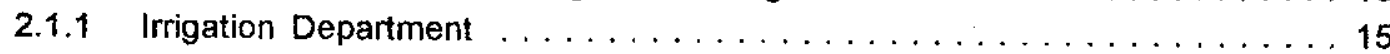

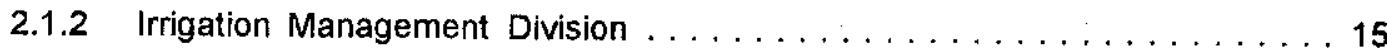

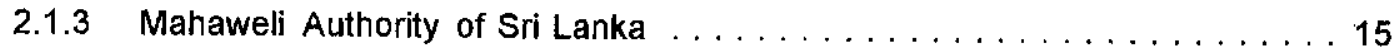

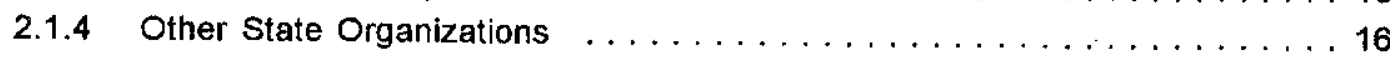

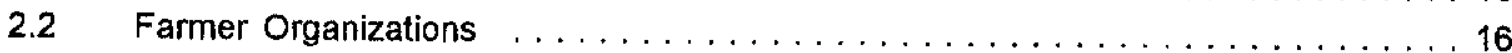

2.3 Communication Between Organizations $\ldots \ldots \ldots \ldots \ldots \ldots \ldots \ldots \ldots$

2.4 Description of Irrigation Schemes $\ldots \ldots \ldots \ldots \ldots \ldots \ldots \ldots \ldots \ldots \ldots \ldots$

2.4.1 Basic Physical Characteristics of the Five Schemes . . . . . . . . . . 18

2.4.2 Dewahuwa Scheme ......................... 18

2.4.3 Mapakada Scheme ......................... 19

2.4.4 Parakrama Samudra Scheme . . . . . . . . . . . . . . . . . . . . 19

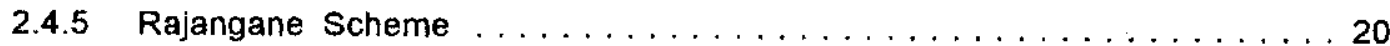

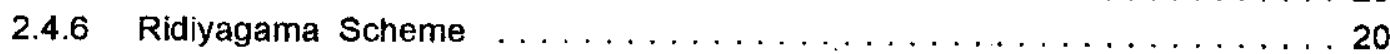




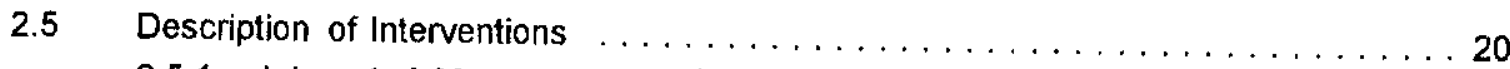

2.5.1 Integrated Management of Irrigation Systems (INMAS) . . . . . . . 20

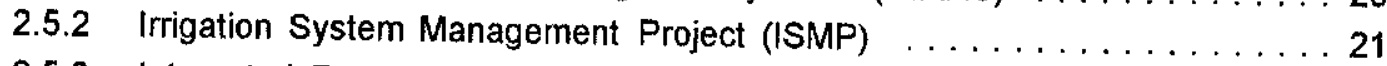

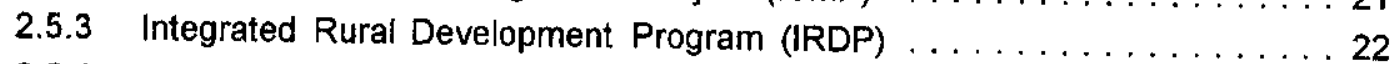

2.5.4 Major Irrigation Rehabilitation Project (MIRP) $\ldots \ldots \ldots \ldots \ldots \ldots \ldots \ldots 22$

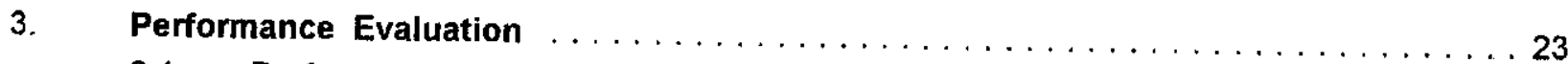

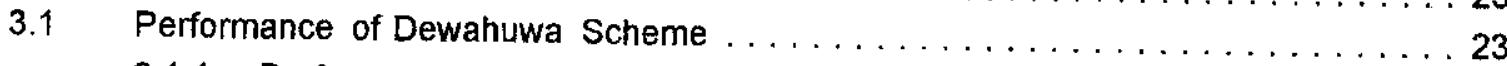

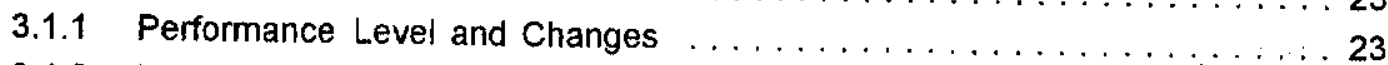

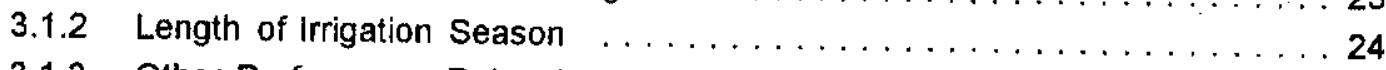

3.1.3 Other Performance-Related Parameters $\ldots \ldots \ldots \ldots \ldots \ldots \ldots \ldots$

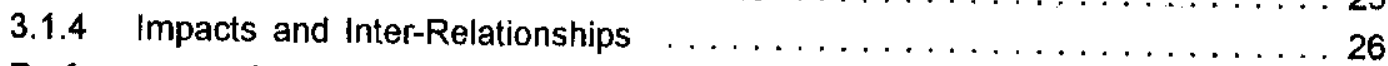

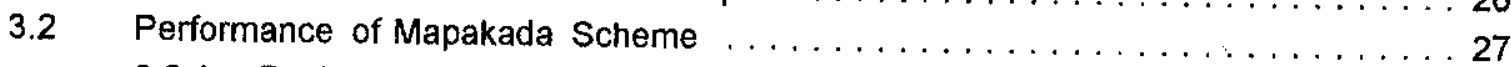

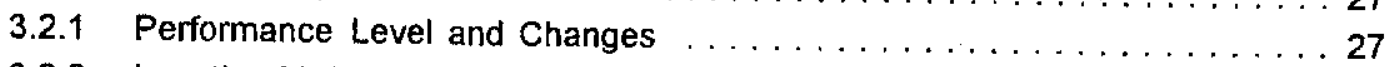

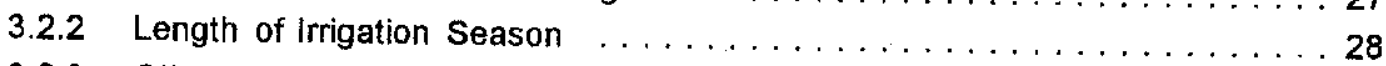

3.2.3 Other Performance-Related Parameters $\ldots \ldots \ldots \ldots \ldots \ldots \ldots \ldots \ldots . \ldots . \ldots$

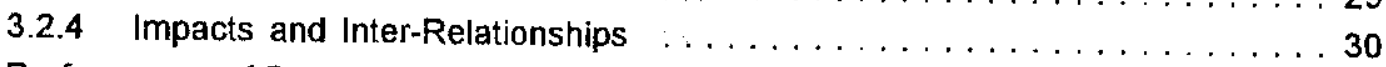

3.3 Performance of Parakrama Samudra Scheme $\ldots \ldots \ldots \ldots \ldots \ldots \ldots$

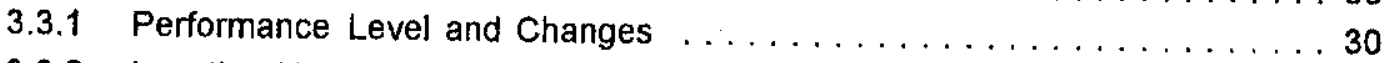

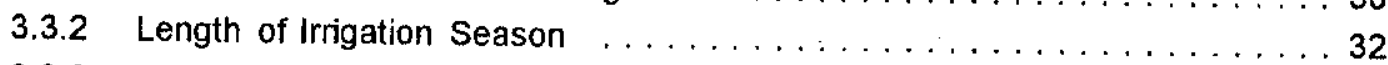

3.3.3 Other Performance-Related parameters $\ldots \ldots \ldots \ldots \ldots \ldots \ldots \ldots \ldots \ldots \ldots \ldots$

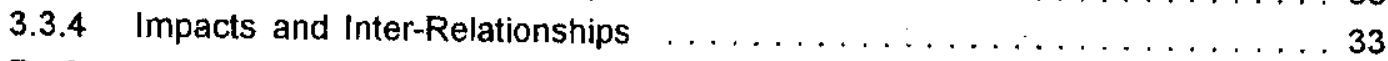

3.4 Performance of Rajangane Scheme $\ldots \ldots \ldots \ldots \ldots \ldots \ldots \ldots \ldots \ldots \ldots \ldots$

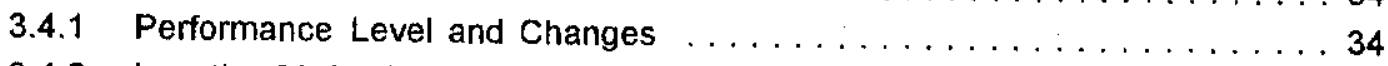

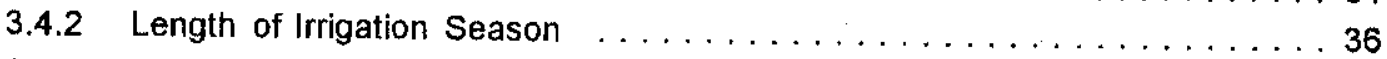

3.4.3 Other Performance-Related Parameters $\ldots \ldots \ldots \ldots \ldots \ldots \ldots \ldots \ldots \ldots$

3.4.4 Impacts and Inter-Relationships $\ldots \ldots \ldots \ldots \ldots \ldots \ldots \ldots \ldots \ldots$

3.5 Performance of Ridiyagama Scheme $\ldots \ldots \ldots \ldots \ldots \ldots \ldots \ldots \ldots \ldots$

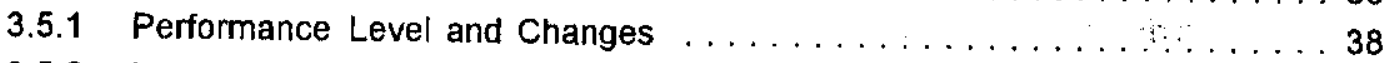

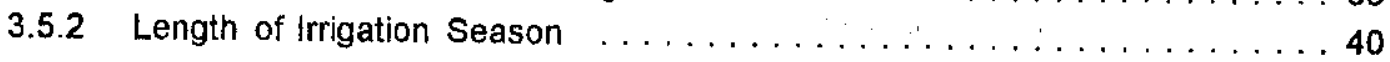

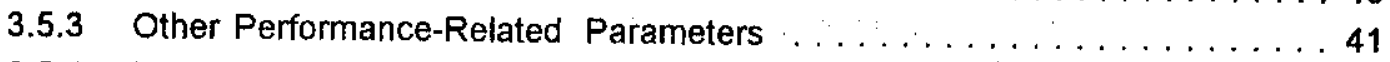

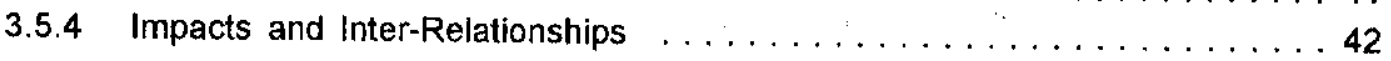

4. A Comparison of Five Irrigation Schemes $\ldots \ldots \ldots \ldots \ldots \ldots \ldots \ldots$

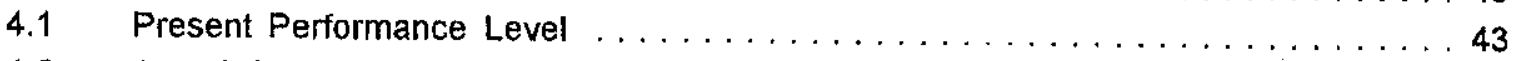

4.2 Area Irrigated per Unit Water $\ldots \ldots \ldots \ldots \ldots \ldots \ldots \ldots \ldots \ldots \ldots \ldots \ldots$

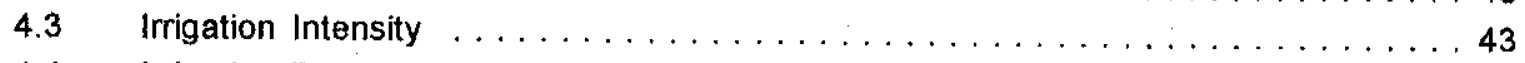

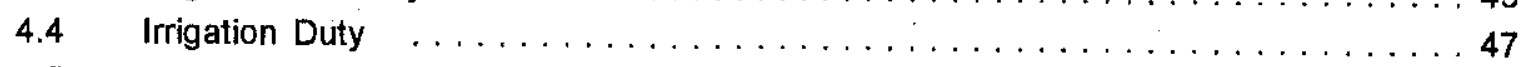

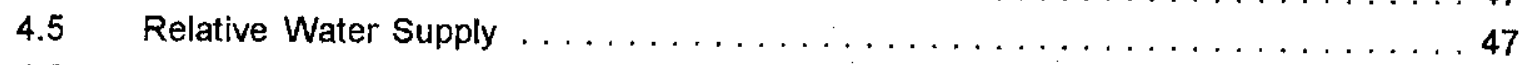

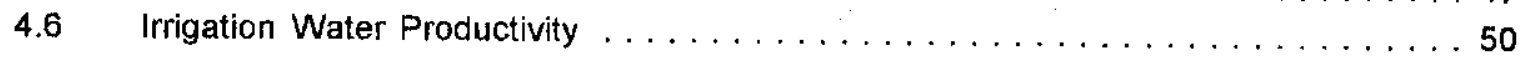

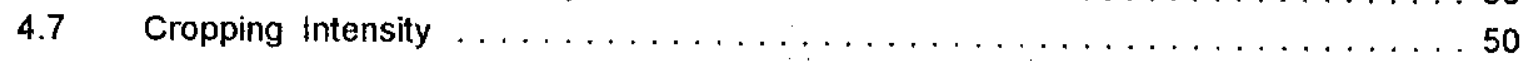

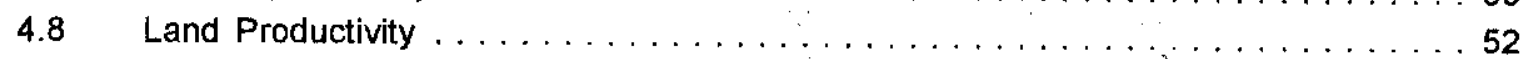

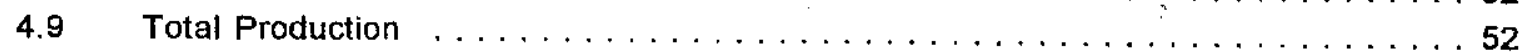




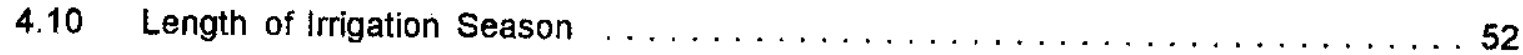

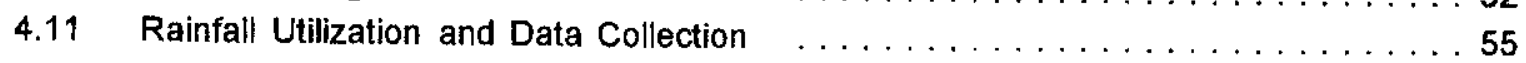

4.12 Cropping Calendar and Weather Pattern $\ldots \ldots \ldots \ldots \ldots \ldots$

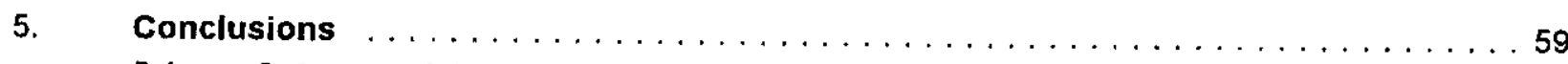

5.1 Outcome of the Study $\ldots \ldots \ldots \ldots \ldots \ldots \ldots \ldots \ldots$

5.1.1 Performance Changes and Inter-Scheme Comparisons . . . . . . . 59

5.1 .2 Comparison of Performance Levels with Potential . . . . . . . . .61

5.2 Factors Contributing to Performance Gains and Achievement of Potential . . . 62

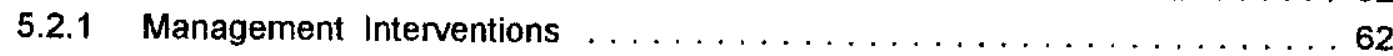

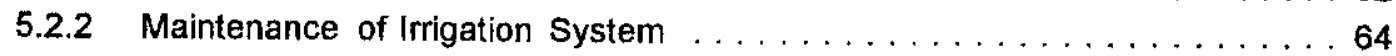

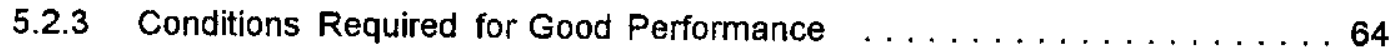

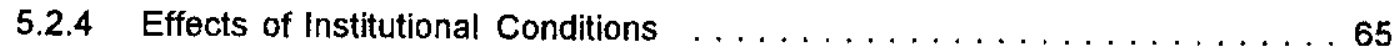

5.2.5 Effectiveness of the Management Cycle $\ldots \ldots \ldots \ldots \ldots$

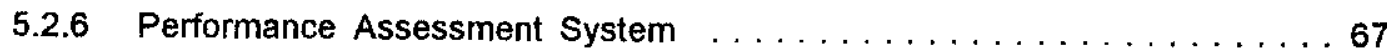

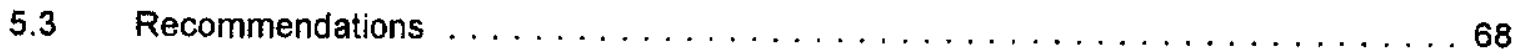

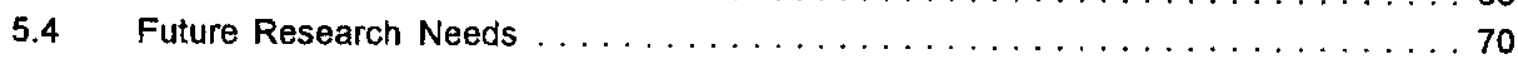

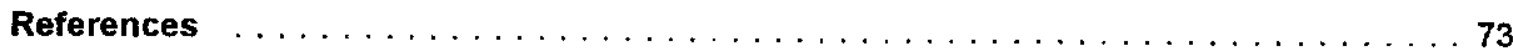




\section{Figures}

Figure 1. Trends of Rice Yield and Cropping Intensity, $1950-1990 \ldots \ldots \ldots \ldots$

Figure 2. Ratio of harvested area to planted area $\ldots \ldots \ldots \ldots \ldots \ldots \ldots \ldots \ldots$

Figure 3. Location of irrigation systems and agro-ecological regions $\ldots \ldots \ldots \ldots \ldots$

Figure 4. Location of irrigation systems and rainfall patterns $\ldots \ldots \ldots \ldots \ldots \ldots$

Figure 5. Area Irrigated per Unit Water (irrigation supply) $\ldots \ldots \ldots \ldots \ldots \ldots \ldots$

Figure 6. Area Irrigated per Unit Water (total water supply) $\ldots \ldots \ldots \ldots \ldots \ldots$

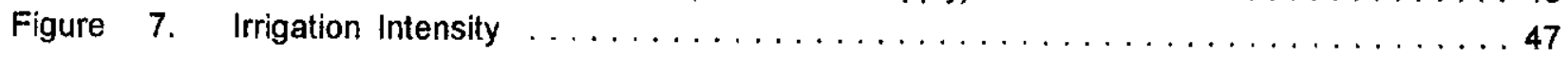

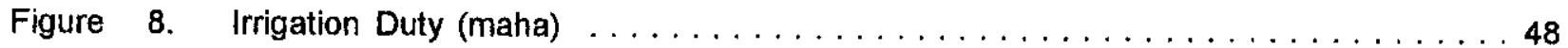

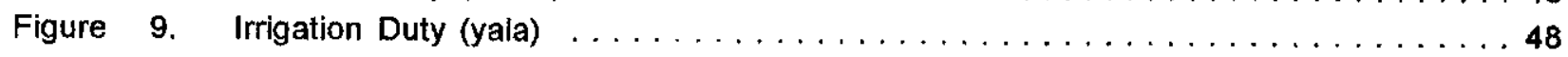

Figure 10. Relative Water Supply (maha) $\ldots \ldots \ldots \ldots \ldots \ldots \ldots \ldots \ldots \ldots$

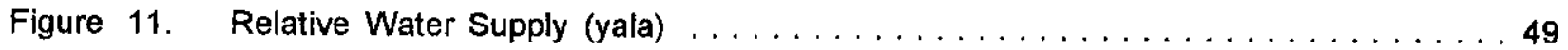

Figure 12. Irrigation Water Productivity (maha) $\ldots \ldots \ldots \ldots \ldots \ldots \ldots \ldots \ldots \ldots \ldots \ldots$

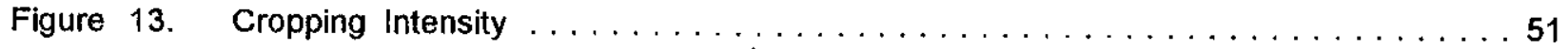

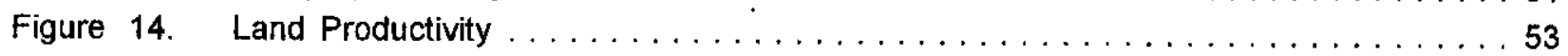

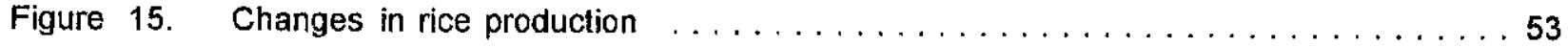

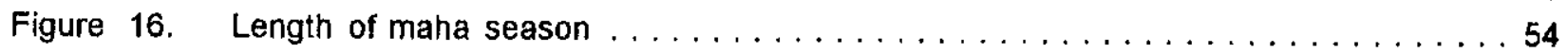

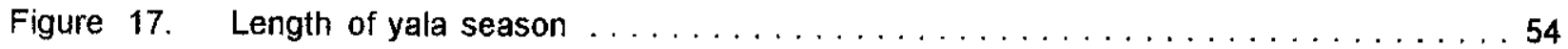

Figure 18. Rainfall in DL1 Agro-Ecological Region $\ldots \ldots \ldots \ldots \ldots \ldots \ldots$

Figure 19. Suggestions to improve the effectiveness of the management cycle . . . . . . . 69 


\section{Tables}

Table 1. Changes in rice land area (area in $1,000 \mathrm{ha}) \ldots \ldots \ldots \ldots \ldots$

Table 2. Statistics of rice cultivation for the period, $1987-1991 \ldots \ldots \ldots \ldots \ldots \ldots \ldots$

Table 3. Changes in population statistics from $1975 \ldots \ldots \ldots \ldots \ldots \ldots \ldots \ldots \ldots \ldots \ldots$

Table 4. Irrigation schemes selected for the study $\ldots \ldots \ldots \ldots \ldots \ldots \ldots \ldots \ldots \ldots \ldots \ldots$

Table 5. Basic physical characteristics of the five schemes $\ldots \ldots \ldots \ldots \ldots \ldots \ldots \ldots$

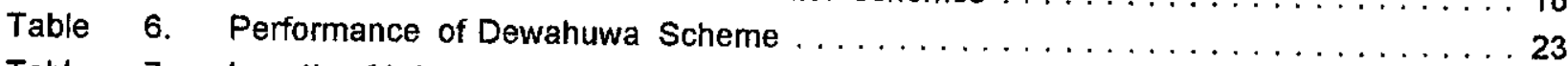

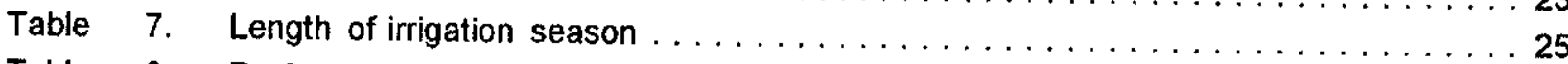

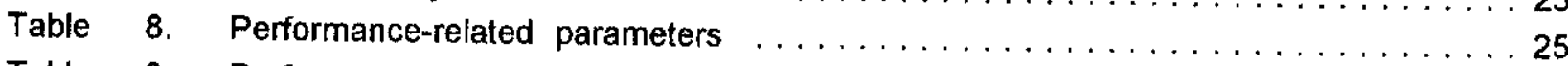

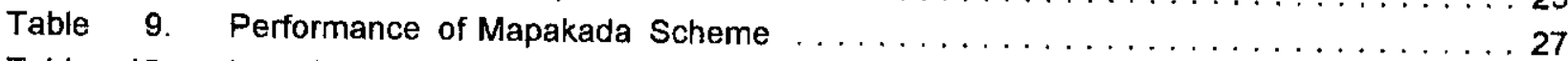

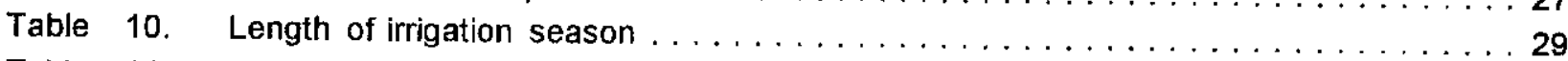

Table 11. Performance-related parameters . . . . . . . . . . . . . . . . . . 29

Table 12. Performance of Parakrama Samudra Scheme $\ldots \ldots \ldots \ldots \ldots \ldots \ldots \ldots \ldots \ldots$

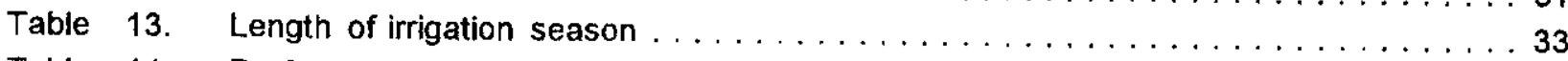

Table 14. Performance-related parameters $\ldots \ldots \ldots \ldots \ldots \ldots \ldots \ldots \ldots \ldots \ldots \ldots \ldots \ldots$

Table 15. Performance of Rajangane Scheme $\ldots \ldots \ldots \ldots \ldots \ldots \ldots \ldots \ldots \ldots \ldots \ldots$

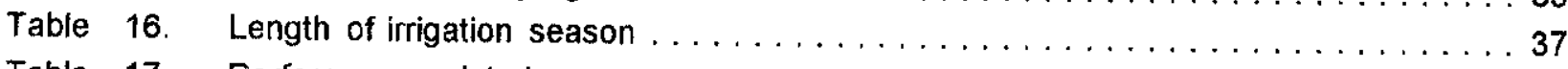

Table 17. Performance-related parameters $\ldots \ldots \ldots \ldots \ldots \ldots \ldots \ldots \ldots \ldots \ldots \ldots \ldots \ldots$

Table 18. Performance of Ridiyagama scheme $\ldots \ldots \ldots \ldots \ldots \ldots \ldots \ldots \ldots \ldots \ldots \ldots$

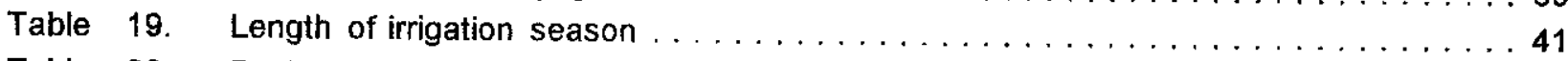

Table 20. Performance-related parameters $\ldots \ldots \ldots \ldots \ldots \ldots \ldots \ldots \ldots \ldots \ldots \ldots \ldots \ldots \ldots$

Table 21. Irrigation performance of the five schemes . . . . . . . . . . . . . 44

Table 22. Irrigation performance-related parameters of the five schemes $\ldots \ldots \ldots \ldots \ldots$

Table 23. A comparison of performance in relation to RWS . . . . . . . . . . . . 50

Table 24. Current irrigation performance as a ratio of the best achievement in the study period 


\title{
Preface
}

This working paper is the outcome of a data collection process initiated under the advice of Dr. Shigeo Yashima of the International Irrigation Management Institute (IIMI). The objective of this data collection process was to make a preliminary assessment of irrigation performance in Sri Lanka using irrigation systems with different backgrounds to identify areas for further research.

The data were collected from the Irrigation Department, the Irrigation Management Division and the Agriculture Department. Grateful acknowledgment is made of these organizations for their cooperation. We wish to make a special mention of the following personnel from these three organizations.

In the Irrigation Department, we wish to thank Mr. D.W.R. Weerakoon, Senior Deputy Director for Operation and Maintenance and Mr. Linton Wijesooriya, Senior Deputy Director for Rehabilitation, for allowing us to use the data and for their assistance in the selection of schemes. Our thanks are also due to Mr. G.T. Dharmasena, Deputy Director of the Hydrology Division, for releasing rainfall figures of the Ridiyagama Scheme. We also wish to thank the Irrigation Engineers Nihal Palipana, Sriyani Weeratunga, Manel Fernando, Sarath Wijesekara and Shirley Perera, for various forms of assistance including the locating of missing data for us.

In the Irrigation Management Division, the cooperation extended to us by the Additional Directors, Mr. W.H.E. Premaratne and Mr. S. Dhanansooriya, are greatly appreciated. In addition, we wish to express our gratitude to the Project Managers of Dewahuwa, Nagadeepa, Parakrama Samudra, Rajangane and Ridiyagama, for providing data.

We also wish to make use of this opportunity to extend our sincere thanks to Mr. J.K.V. Ranjith, Assistant Director of the Agriculture Department, Hambantota, for his quick response to our requests for data.

Dr. R. Sakthivadivel kindly consented to review this document. This work immensely benefited from his comments and suggestions. The support and advice provided to us by Dr. Ramesh Bhatia as the leader of the Performance Program are also gratefully acknowledged.

Finally, it must be stated that the first author has been responsible for data collection and analysis and writing the first drafts of this paper during the period he worked as a Research Officer at IIMI. The second author's role has been to support and assist the efforts of the former. However, both authors are jointly and fully responsible for the paper.

\author{
K.A.U.S. Imbulana \\ Irrigation Department
}

Douglas J. Merrey

International Irrigation Management Institute 


\section{Executive Summary}

Sri Lanka's irrigation systems have evolved through centuries to their present state. A rapid expansion of irrigated agriculture, especially rice cultivation, was experienced after independence in 1948. However, cropping intensity and ratio of harvested area to planted area do not show an appreciable improvement in comparison to the increase in irrigated area and crop yields. This is despite various interventions made to improve irrigation performance, including structural rehabilitation and increased farmer participation in management.

This situation gives rise to three research questions on irrigated agriculture in Sri Lanka. They are as follows:

1. Is the full performance potential of irrigation systems being realized?

2. Why do the irrigation systems achieve or not achieve their potential?

3. Is the present data collection system (of national agencies) adequate to make an effective assessment of irrigation performance?

This study makes a preliminary assessment of the performance of five irrigation systems in Sri Lanka, with a view to answering these research questions. It was intended to achieve this through meeting the following specific objectives:

1. Assessing the impact of management interventions on the performance of irrigation systems.

2. Comparing the water use and performance levels among the five irrigation systems.

3. Suggesting improvements in data collection and performance assessment procedures practiced at present by Sri Lankan irrigation agencies.

The Dewahuwa, Mapakada, Parakrama Samudra, Rajangane and Ridiyagama irrigation schemes were selected for the study. The interventions assessed by this study include crop diversification, structural improvements, and shared management with farmers. In Ridiyagama there were no interventions of significance until 1990.

The results show significant performance gains in water use and productivity in the Rajangane Scheme. The results are mixed in Parakrama Samudra-where performance related to water use has improved while agricultural performance has declined-and in Mapakada-where agricultural performance has increased while water use performance has declined. In Dewahuwa and Ridiyagama, performance has declined with respect to several performance indicators.

The results identify a single factor which has influenced the performance gains related to water usedecreasing the length of the irrigation season. They indicate that interventions which combine both structural and institutional improvements have greater impacts on performance. The following features of management interventions have been found to contribute to good performance: 
1. Heavy management bias in rehabilitation projects.

2. Active farmer participation in rehabilitation projects.

3. Farmer participation in management of the system.

4. Structural improvements.

5. Facilities to improve water management.

6. Agronomic practices leading to low water use per unit land.

The following factors impede performance gains:

1. Lack of motivation due to good water availability.

2. Deviation from the usual cropping calendar.

3. Preparation of irrigation schedules without regard of the rainfall pattern.

Further, it appears that overall, Operation and Maintenance (O\&M) funds allocated to the Irrigation Department are insufficient to meet the maintenance requirements. This can lead to deterioration of the system even after structural improvements.

A comparison with the best performance recorded during the study period (1984 to 1993), indicates that the irrigation systems are operating below their potential. The results also indicate that full use of rainfall is not made, that the emphasis on water management in some interventions is inadequate, that the length of the irrigation season could be further reduced, and that there is in general stagnation or even decline in the performance of these systems on most parameters. These factors also support the hypothesis that the irrigation systems are operating below their potential.

Because the scope of the available data is limited, a literature survey was made to identify other factors which could lead to achieving the potential performance. Such factors include institutional conditions which provide incentives for good performance, presence of a management cycle through which managers plan, implement, monitor and evaluate their work with the aim of achieving the objectives, and regular assessment of irrigation performance.

The present performance assessment system used by the national agencies seems to be inadequate to make a meaningful contribution to irrigation performance. The data collection system has many shortcomings. Several suggestions are made to improve the performance assessment and data collection systems. They include sharing of the data collected by different national agencies, soliciting farmer cooperation and participation in data collection, and adopting computerized Irrigation Management Information Systems (IMIS). 


\section{Introduction}

\subsection{BACKGROUND}

\subsubsection{Physical Setting}

Sri Lanka has a tropical monsoon climate due to its close proximity to the equator. The main contribution to the total annual rainfall is from the monsoonal rains. The northern and eastern parts of the country receive the major part of their rainfall from the northeastern monsoon, from October to March. The southwestern monsoon, which occurs from March to September, provides most of the rain for the southwestern and western parts of the island. The rainfall pattern divides the country into a Dry Zone and a Wet Zone, at the 1.9 meters $(m)$ isoheyt (Framji et al. 1983). A more detailed classification divides the country into a Dry Zone, an Intermediate Zone and a Wet Zone: In the Dry Zone the annual rainfall is less than 1,905 millimeters $(\mathrm{mm})$, and in the Wet Zone the annual rainfall is more than $2,540 \mathrm{~mm}$ (Jayawardane and Jayasinghe 1992).

There are two cultivation seasons in Sri Lanka. The rainy season called maha is from October to March, and the dry season called yala comes between March and September.

\subsubsection{Historical Development of Irrigation in Sri Lanka}

Numerous studies have been conducted on the hydraulic civilization in Sri Lanka. These studies have been facilitated by the survival of sections of the ancient irrigation systems.

Researchers have adopted different approaches to explain the evolution of irrigation systems in Sri Lanka. According to the irrigation eco-system approach, the evolution took place in several stages. Starting with rain-fed agriculture, the irrigation methods developed through river diversion structures and the associated channel system to the more elaborate storage reservoirs equipped with sluices and access towers (Mendis 1989). According to the records kept from ancient times, the oldest existing reservoir was built in the 4th century B.C. in the North Central Province (Arumugam 1969). Since then, the subsequent monarchs built a large number of irrigation works. But after the 12th century, the irrigation systems began to deteriorate. The British, who occupied the entire island after 1815, renovated a large number of ancient irrigation works, and initiated land policies for the new settlers (Arumugam 1969).

In 1948, Sri Lanka gained independence from the British. Two of the most significant events related to irrigation in post-independent Sri Lanka were the completion of the Gal Oya Scheme in the Eastern Province in the 1950s, and the completion of the Mahaweli Development Program in the late 1980s.

\subsubsection{Present Status of Irrigation Performance}

The percentage of irrigated land in Sri Lanka is about 60 percent of the total arable lands (FAO 1991). The major portion of the irrigated land is planted with paddy (rough rice). For example, the area 
cultivated with nonrice crops under irrigation in 1991 was 29,225 hectares (ha) in maha and 42,146 ha in yala (Jayawardane et al. 1993), out of approximately 550,000 ha of irrigated land. This is despite recent attempts to diversify the crops in irrigation schemes. As a result, the changes in irrigated area can be approximated with changes in rice planted area under irrigation.

Sixty-one percent of the irrigated land comes under major irrigation schemes, which are defined as schemes with command areas of 80 ha or more. Lands under major irrigation schemes have increased by 160 percent in the last 30 years, while the increase in the total land irrigated to rice was 60 percent for the same period (see Table 1).

Table 1. Changes in rice land area (area in 1,000 ha).

\begin{tabular}{|c|c|c|c|c|c|}
\hline \multirow{2}{*}{ Period } & \multicolumn{2}{|c|}{ Irrigated land } & \multirow{2}{*}{$\begin{array}{l}\text { Total irrigated } \\
\text { land }\end{array}$} & \multirow[t]{2}{*}{ Rain-fed land } & \multirow{2}{*}{$\begin{array}{c}\text { Total agricultural } \\
\text { land }\end{array}$} \\
\hline & Major schemes & Minor schemes & & & \\
\hline $1950-59$ & 114.2 & 167.7 & 281.9 & 161.1 & 443.0 \\
\hline $1960-69$ & 160.9 & 175.9 & 337.7 & 183.8 & 521.5 \\
\hline $1970-79$ & 226.8 & 184.1 & 414.1 & 212.3 & 626.4 \\
\hline $1980-87$ & 294.8 & 185.2 & 483.7 & 220.3 & 704.0 \\
\hline
\end{tabular}

$\begin{array}{ll} & \text { Includes area under lift irrigation } \\ \text { Source: } \quad \text { Aluwihare and Kikuchi } 1990 .\end{array}$

Rice is the staple food of the majority of Sri Lankans. The country can be proud of the developments in rice production after independence in 1948. Rice production, as a percentage of the total requirement, has increased from about 40 percent immediately after independence to about 90 percent in the mid1980s (Aluwihare and Kikuchi 1990). Table 2 describes the present situation of rice cultivation.

Table 2. Statistics of rice cultivation for the period, 1987-1991.

\begin{tabular}{||r|r|r|r|}
\hline \multicolumn{1}{|c|}{ Parameter } & $\therefore$ Maha & Yala & Total \\
\hline Cropping Intensity & 70.0 & 41.1 & 111.1 \\
Yield (kg/ha-rough rice) & $3,546.2$ & $3,265.0$ & $3,405.6$ \\
Production (1,000 $\mathrm{mt}$ ) & $1,492.0$ & 826.6 & $2,318.6$ \\
\hline
\end{tabular}

Source: Department of Census and Statistics 1992.

Yield increases resulting from the development of improved varieties of rice and increases in the area" irrigated, contributed to this success. Irrigated land area was increased through large investments in irrigation infrastructure, in the form of new construction, restoration of ancient schemes, and rehabilitation. The Mahaweli Development Program also contributed to the increase in the irrigated area. The development of most of the river basins for irrigation is now complete. 
However, whether the full potential of irrigation is being achieved is a matter of concern. Figure 1 , where Rice Yield and Cropping Intensity as a ratio of the base value at 1950 are plotted, compares the increases of those two parameters since 1950. It shows that the increase in Cropping Intensity has not kept pace with the increase in yield or the increase in irrigated land shown in Table 1. The present level of Cropping Intensity, given in Table 2, appears to be low.

Figure 1. Trends of Rice Yield and Cropping Intensity, 1950-1990.

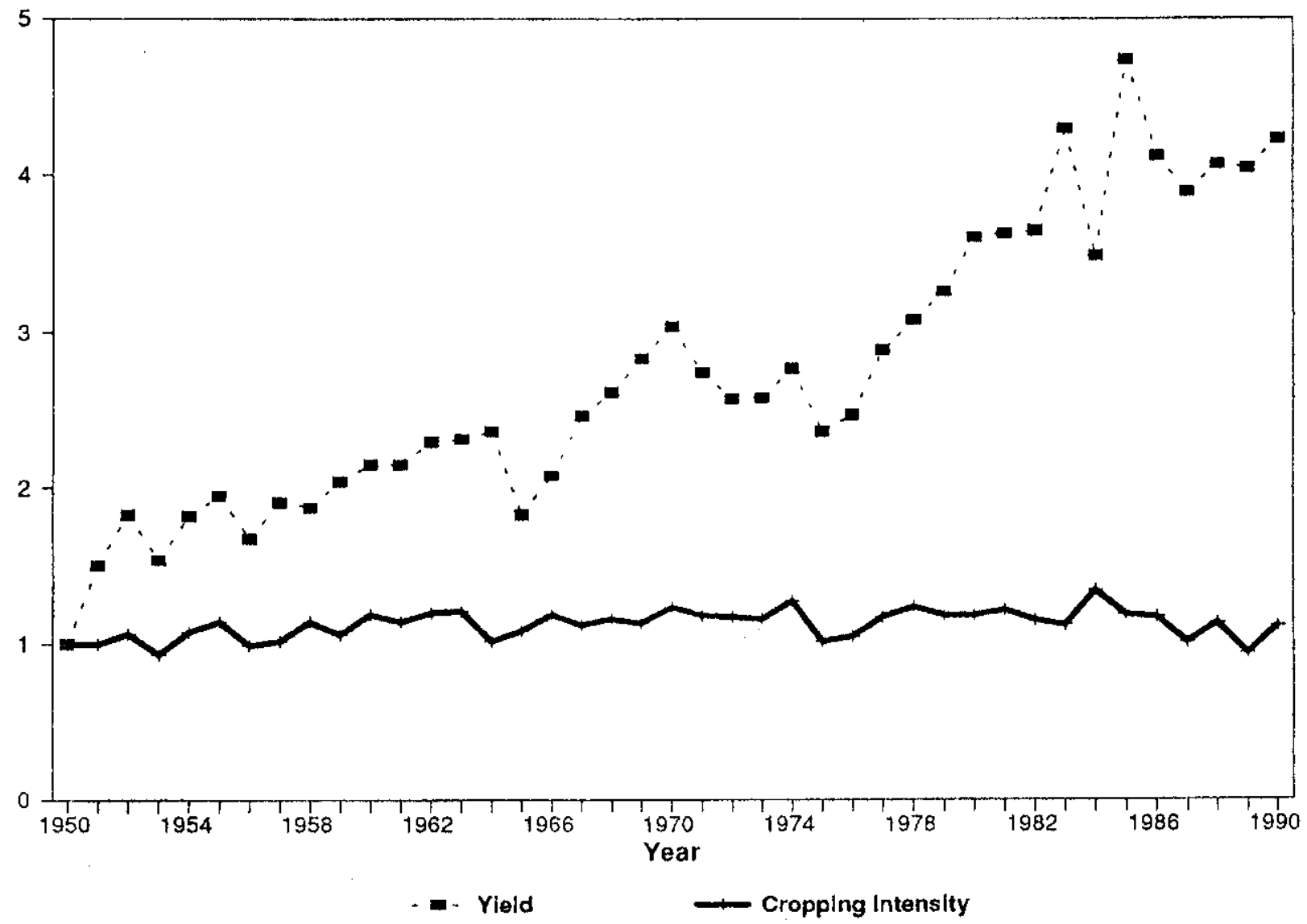

Sources: Aluwihare and Kikuchi 1990 and Department of Census and Statistics 1992.

Figure 2 shows that the ratio of harvested area to planted area has been fluctuating over the years. There seems to be no appreciable increase in this ratio, indicating that the dependability of agricultural production has not improved. 
Figure 2. Ratio of harvested area to planted area.

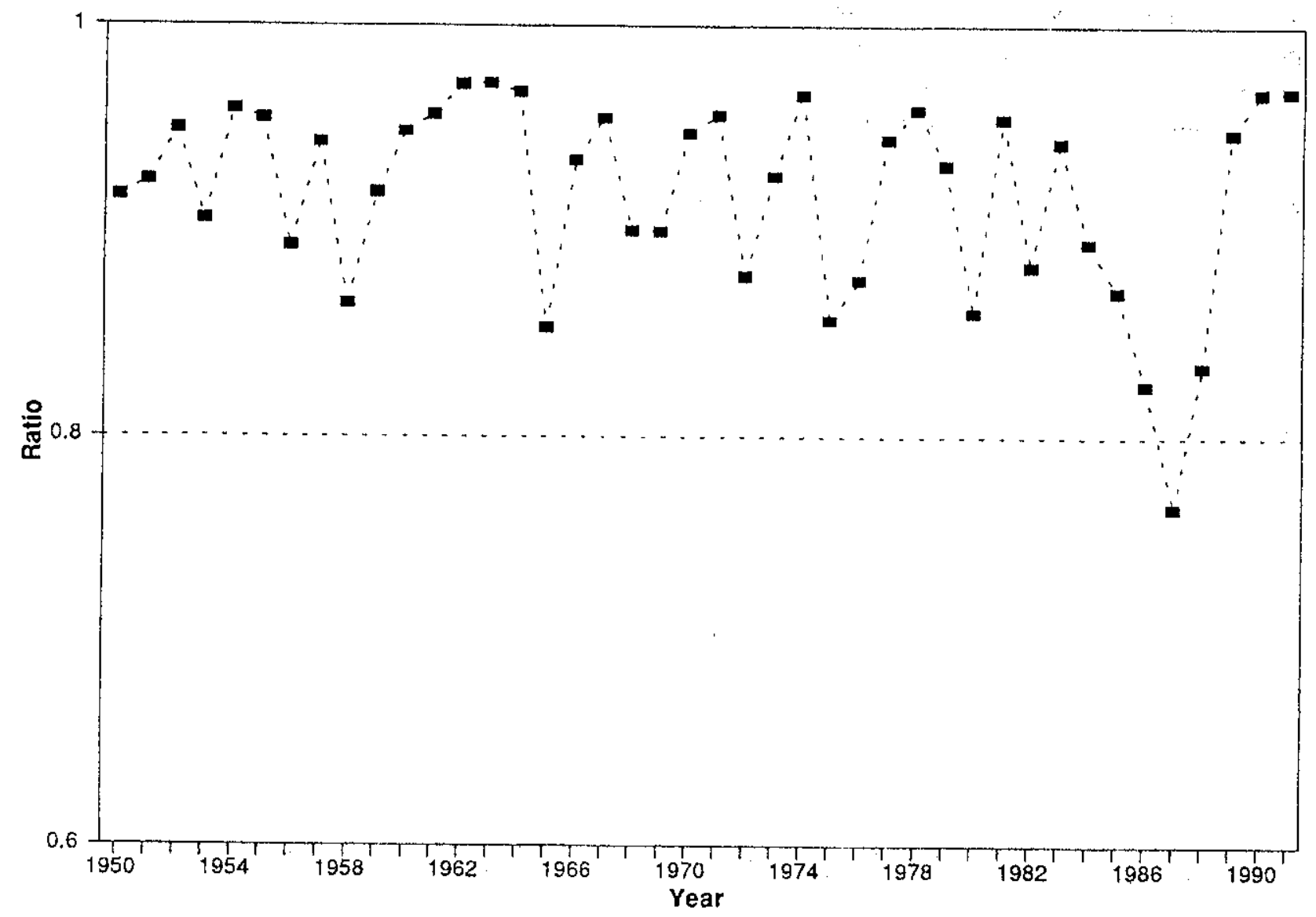

Sources: Aluwhare and Kikuchi 1990 and Department of Census and Statistics 1992.

This is not a very satisfactory situation, because Table 3 shows that the population depending on agriculture for its livelihood has increased by about 20 percent in the period from 1975 to 1990 . In the same period, the economically active population in agriculture has increased by about 27 percent, although agricultural workers as a percentage of the economically active population has slightly decreased from 54.3 to 51.7 percent. These figures show that a substantial proportion of the population of Sri Lanka is engaged in agriculture for a living. Inadequate alternative employment may have forced people to remain engaged in agriculture. But inadequate benefits will have undesirable social effects, as witnessed in two armed rebellions by the rural youth within the past 25 years. 
Table 3. Changes in population statistics from 1975.

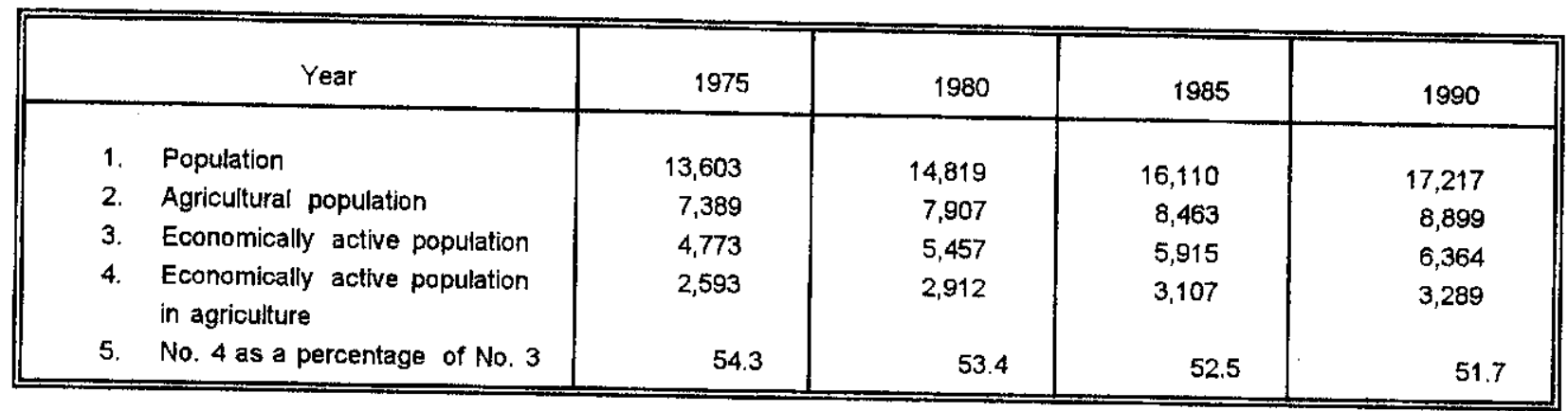

Source: $\quad$ FAO Production Yearbook 1990.

\subsection{RESEARCH OBJECTIVES AND RESEARCH QUESTIONS}

\subsubsection{Research Questions}

The highest level of performance which can be achieved given the available resources, such as water, land and crop varieties, can be defined as the "full potential performance" of an irrigation system. The level of performance is measured by indicators such as Cropping Intensity.

The irrigation sector statistics discussed above show that although the area with irrigation facilities has increased, the Cropping Intensity has not increased significantly during the past forty years. Several reasons can be suggested for this. One is that the command areas under a large number of irrigation schemes have increased from their original designed area. As shown in the following sections, the specified areas of the irrigation schemes selected for this study have increased by amounts ranging from 4 to 45 percent. As a result, sometimes the water resources may be inadequate to achieve the originally designed Cropping Intensity. Another reason is the poorly planned exploitation of the watershed which results in reducing the inflow to the reservoirs. An example for this is the Mahakanadarawa Scheme in the North Central Province which experiences an acute shortage of water due to the rehabilitation of several smaller tanks in the watershed (Abeysekera 1993).

However, a review of past studies on irrigation management show that there is both a need and an opportunity to improve the water management practices. Many irrigation schemes still do not have measuring devices at secondary canal level. The problems associated with water supply and control include inequity and unreliability (Fowler and Kilkelly 1987a). These observations form the basis for the first research question: Is the full potential performance in irrigation systems being realized?

As discussed above, many factors contribute to the inability of irrigation systerns to achieve their potential performance. Management interventions are made with the intention of improving the existing performance levels. But researchers sometimes find that those management interventions have not achieved their targets. An irrigation manager who wants to improve the performance of an irrigation system or a policy maker who wants to implement a management intervention is interested in knowing 
the factors which contribute to good performance. Therefore, the second research question is as follows: Why do the irrigation systems achieve or not achieve their potential?

Assessment of performance is a necessary first step to identifying the weak points in the management process which hinder good performance. Similarly, it is important to evaluate whether the management interventions implemented on an irrigation system have achieved their objectives through performance assessment. Therefore, the third research question is as follows: Is the present data collection system adequate to make an effective assessment of irrigation performance?

\subsubsection{Objectives}

The purpose of the present study is to do a preliminary assessment of the performance of five irrigation schemes, using available data, and to provide a base for future studies on performance. It is also expected that this exercise will provide an insight into the data availability, quality of data and data needs for comprehensive performance assessment.

The specific objectives of the study are as follows:

1. To assess the impact of management interventions on the performance of irrigation systems.

2. To compare water use and performance levels among the five irrigation systems.

3. To suggest improvements in data collection and performance assessment procedures practiced at present by Sri Lankan irrigation agencies.

The present study provides an insight into the adequacy of data bases maintained by Sri Lankan irrigation agencies for the assessment of performance of their irrigation systems and management innovations. It will also contribute to the establishment of a database of comparative information on different irrigation systems.

\subsection{RESEARCH APPROACH}

\subsubsection{Type of Irrigation Systems}

In 1988, the number of major irrigation schemes in Sri Lanka stood at 395 (Wijesooriya 1990). There is a much larger number of minor irrigation systems. These irrigation schemes have widely differing characteristics. Some attributes of the irrigation schemes which can influence irrigation performance are as follows:

1. Age of the irrigation system.

2. Whether the system was recently rehabilitated or not.

3. Water availability. 
4. Location.

5. Size of the system.

6. Management system.

7. Whether the scheme is an old scheme or a new settlement.

8. Design principles and methodology.

To create a representative sample of irrigation systems in Sri Lanka, the ideal sample should be stratified using all the above attributes. However, data and resource limitations have restricted the selection of irrigation systems. Therefore, this study is exploratory, not definitive; its results would require further validation before generalizations can be made about irrigation system performance in Sri Lanka.

\subsubsection{Basis of Selection}

The selection of irrigation schemes comes under and was based on discussions with the Irrigation Department (ID). The following were also considered in this regard:

1. Schemes should cover as many different attributes as possible.

2. Schemes should cover a variety of interventions intended to improve performance.

3. Data available in the head office should be as continuous as possible.

The selected irrigation schemes are listed in Table 4. Their locations in relation to agro-ecological regions and rainfall patterns are shown in Figures 3 and 4, respectively.

Table 4. Irrigation schemes selected for the study.

\begin{tabular}{|l|r|r|}
\hline \multicolumn{1}{|c|}{ Scheme } & $\begin{array}{r}\text { Command area } \\
\text { (ha) }\end{array}$ & Intervention \\
\hline Dewahuwa & 1,214 & 548 \\
Mapakada & 9,794 & INMAS, crop diversification \\
Parakrama Samudra & 5,600 & IRDP, INMAS \\
Rajangane & 3,440 & ISMP, INMAS \\
Ridiyagama & MIRP, INMAS \\
INMAS
\end{tabular}

Notes: $\begin{array}{ll}\text { INMAS } & =\text { Integrated Management of Major Irrigatlon Schemes. } \\ \text { IRDP } & =\text { Integrated Rural Development Program. } \\ \text { MIRP } & =\text { Major Irrigation Rehabilitation Project. } \\ \text { ISMP } & =\text { Irrigation System Management Project. }\end{array}$


Figure 3. Location of irrigation systems and agro-ecological regions.

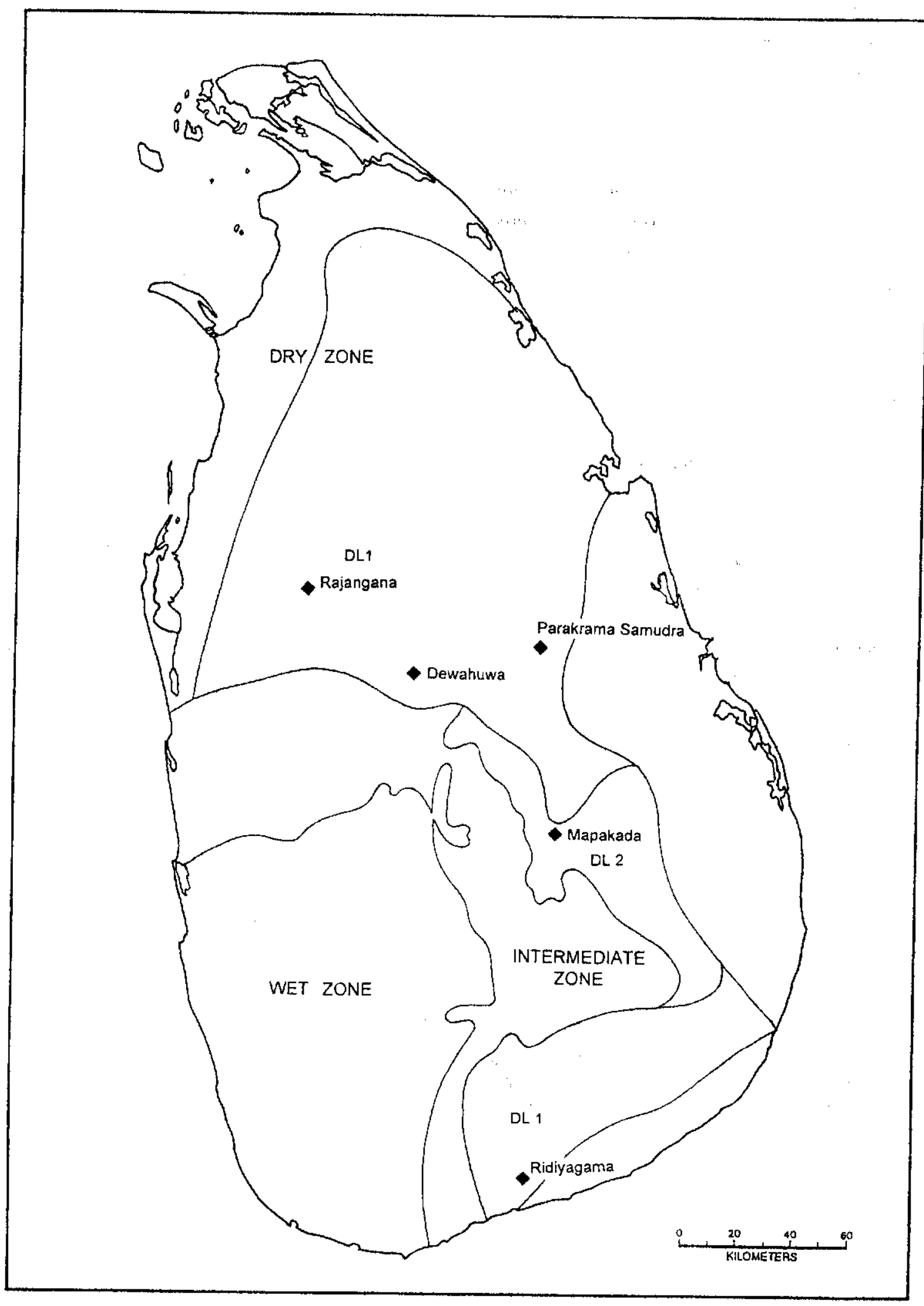




\section{a. Area Irrigated per Unit Water (ha/MCM)}

This is calculated per unit of irrigation supply and per unit of total water supply separately. The total water supply is defined as the sum of rainfall and irrigation supply.

Effective rainfall is a complex parameter to calculate, because it is dependent on the depth of water in the field before the rainfall event, intensity and duration of rainfall, field bund heights, crop characteristics, and soil characteristics. As the data are insufficient to calculate effective rainfall accurately, it was decided to use the value of rainfall without adjustment in the analysis.

Considering the fact that the results would be used only for comparison, it is expected that inaccuracies introduced by these approximations would be minimal.

\section{b. Irrigation Intensity}

Irrigation intensity is defined as the gross irrigated area divided by the cultivable command area (Muralidaran and Krishna 1993). The cultivable command area used here is the present area and not the design area.

The value of this indicator will indicate the water availability to the system as well as the changes in land utilization as a result of management interventions.

\section{c. Irrigation Duty}

Irrigation Duty is used as an indicator here because it is widely used in Sri Lanka and design values are available. It is defined as the amount of water delivered from the sluice to the farm for land preparation and crop water requirement (Ponrajah 1988). It is expressed as the area irrigated per unit discharge and also as a depth.

According to Technical Note 6 of the Irrigation Department, the Irrigation Duty for 135 day rice in maha is $1.33 \mathrm{~m}(4.36 \mathrm{ft}$.), and for 105-day rice in yala, $1.7 \mathrm{~m}(5.56 \mathrm{ft}$.). These estimates are based on 75 percent probability level long-term rainfall and uniform values for evaporation, seepage and percolation. As a result, these values need to be modified to suit the actual field conditions in irrigation scheduling. However, they can be used as reference values to compare with design stage estimations. To facilitate this comparison, the actual Irrigation Duty is expressed in this study as a depth.

\section{d. Relative Water Supply}

Relative Water Supply (RWS) is generally defined as the ratio of supply to demand (Levine 1982) in irrigation planning, design and operation. While the water supply is considered to be the sum of irrigation supply and effective rainfall, water demand comprises of crop evapotranspiration, seepage and percolation losses. The minimum value of RWS for optimum production depends on the management pattern of the system (Sakthivadivel et al. 1992).

A slightly different approach was adopted for the Diagnostic Analysis Study conducted in Minneriya and Kaudulla schemes in 1986-87 (Fowler and Kilkelly 1987b). This study defines water requirement as the difference between crop water requirement and effective rainfall. The water requirement further 


\subsection{SCOPE AND METHODOLOGY}

\subsubsection{Scope of the Study}

The Irrigation Department of Sri Lanka has been maintaining water delivery records of the irrigation schemes classified as major schemes since 1984 at its head office. In most irrigation schemes the discharge is measured at the head sluice which delivers water to the main canal. Even though water delivery data are recorded below this level in a few irrigation schemes, these data are not transmitted to the head office.

Gauge readings for water delivery are taken by laborers employed for that purpose. At the Irrigation Engineer's office, these data are converted to discharges, usually by a draughtsman.

Irrigation Engineers are instructed to calibrate the gauge posts when changes to the canal profile occur. In addition, the Hydrology Division of the Irrigation Department conducts water balance studies on major reservoirs. If any discrepancy is detected, gauge posts are calibrated. In some schemes, the gauge posts are calibrated once a year regardless of whether the profile has changed or not. Such decisions are taken at the scheme level.

The data are checked at the Irrigation Engineer's office and are sent to the Range Deputy Director's office and the head office. They are checked once again at these offices, and clarifications of any discrepancies are obtained. At the end of a cultivation season, a seasonal summary is prepared at the head office. The summary includes irrigated area, crop types, total issues, rainfall, cultivation period and irrigation water duty. Clarifications are sought from Irrigation Engineers for any significant shortfalls.

The Irrigation Management Division (IMD), which coordinates the activities of several line agencies, collects agricultural data such as cultivated area, crops and crop yield. These data are obtained through line agencies, farmer organizations and surveys. The Project Managers employed by the IMD convey these data to the head office through their progress reports.

Irrigation Department data are used for the irrigated area and irrigable area, while IMD data are used for the cultivated area. While the irrigated area and cuitivated area can differ, very large differences indicate the possibility of erroneous data. In such cases, the data were not used for performance
estimations.

Irrigation Department data show that the irrigated area has increased over the years in all the schemes. The present value of the irrigable area instead of the designed area was used for the estimation of Irrigation Intensity and Cropping Intensity.

The data collection for this study is restricted to what could be obtained from the Irrigation Department head office and the IMD head office. Because of the late start of the INMAS Project in Ridiyagama, agricultural data for this project were obtained from the Agriculture Department.

\subsubsection{Performance Indicators}

A comprehensive set of performance indicators is being developed by the Performance Program of IIMI. However, the availability of data restricts the selection of indicators. Hence, the following set of indicators was selected considering the available data. 
10 percent deviation $(0.9-1.1)=$ good performance

20 percent deviation $(0.8-1.2)=$ fair performance

More than 20 percent deviation $=$ poor performance

\section{e. Irrigation Water Productivity}

Irrigation Water Productivity in this report is defined as crop production per unit irrigation water. Because of the unavailability of data on the production of Other Field Crops (OFCs), only rice production will be used for the analysis. It is assumed that when the OFC cultivated area is less than 10 percent of the cultivated area, the irrigation issues will not be significantly affected by OFCs and will be based on rice water requirements. Consequently, when the OFC cultivated area exceeds 10 percent of the cultivated area, Irrigation Water Productivity is not calculated due to the uncertainty of water allocation policies.

\section{f. Cropping Intensity}

Cropping Intensity, which is defined as the ratio of total cultivated area to cultivable area, is calculated annually. The year is considered to start with the maha season and end with the yala season. The total cultivated area is obtained from records of the Irrigation Management Division, while the cultivable area is obtained from Irrigation Department records.

\section{g. Land Productivity}

Land Productivity can be defined in two ways. The first is to define it as the ratio of total production for the year to average cultivated area. The value of Land Productivity calculated using this method is related to Cropping Intensity. The second method is to define it as the ratio of total production to total area cultivated (sum of the area cultivated each season), which is in effect the weighted average yield for a single season.

Some of the schemes selected for this study cultivate OFCs in the yala season while others cultivate mainly rice during both seasons. As a result, adoption of the first definition will lead to confusion when the performances are compared, because production from different crops have different values. Hence, using the second method of definition, Land Productivity is defined here as the total production of rough rice divided by the total area cultivated during the year.

\subsubsection{Other Indices}

The length of an irrigation season is used as an index to assess the immediate impact of interventions. The major crop in the selected irrigation schemes is rice. Since the crop growth period is fairly constant, the variable is the land preparation period. Minimizing the land preparation period will result in shorter irrigation periods. This will ultimately result in saving a significant amount of water. It will also provide sufficient time for the maintenance activities.

Timely, adequate and equitable water supply; better communication between farmers and officers; and adherence to the agreed cropping schedule are expected to shorten the irrigation period. As a 
includes losses in the canal up to the delivery point. According to this approach, the optimum value of RWS is 1 .

The present study combines the two approaches. The definition of RWS is the same as that of Levine (1982). But the irrigation supply at the point of interest is estimated using the available information on conveyance losses. As a result, the optimum value of RWS is 1 . This allows the inclusion of different efficiencies of the irrigation conveyance system and rainfall utilization in the RWS calculations.

Since the actual field data on conveyance losses and rainfall losses are not available, the parameters needed to calculate RWS were estimated as follows:

$$
\begin{aligned}
\text { Losses from sluice to farm } & =40 \text { percent } \\
\text { Seepage and percolation rate } & =4 \mathrm{~mm} \text { per day in the Dry Zone } \\
& =6 \mathrm{~mm} \text { per day in the Intermediate Zone } \\
\text { Effective rainfall } & =70 \text { percent in maha } \\
& =100 \text { percent in yala }
\end{aligned}
$$

These values were arrived at after studying the norms set by the Irrigation Department (Ponrajah 1981); the survey of formulae and methods included in Dastane (1974); and the results of field studies done in the Dry Zone (Somapala 1985), Parakrama Samudra (Fowler and Kilkelly 1987a), Minneriya (Fowler and Kilkelly 1987b) and Kaudulla (Abernathy and Weller 1987). The following factors which are not usually included in the formulae and estimates were also considered:

1. Water lost due to seepage and percolation from one rice field is not wasted completely. Part of it seeps into adjoining rice fields. A portion of what is intercepted by the drainage canals is also diverted to the farms.

2. The portion of rainfall which evaporates in the atmosphere without reaching the ground surface contributes to crop water needs by lowering the temperature and increasing the humidity which results in reduced evapotranspiration.

3. Rain which is intercepted by plants and evaporates without reaching the ground is also useful in reducing transpiration (Dastane 1974).

4. The portion of rainfall which spills over field bunds is found to contribute to raising the ground water level. This indirectly reduces the water requirements (Elkaduwa 1990).

5. Since most of the Sri Lankan main canals are designed along contours, a portion of the surface runoff contributes to the canal fiow.

The optimum value of RWS is 1 , which refers to the situation where the supply perfectly matches the demand. Irrigation performance measured by RWS is categorized according to the following standards: 


\section{Irrigation Systems and Their Management}

\subsection{STATE ORGANIZATIONS INVOLVED IN IRRIGATION MANAGEMENT}

\subsubsection{Irrigation Department}

Outside the Mahaweli areas, the construction of irrigation systems and the Operation and Maintenance (O\&M) of all irrigation schemes having a command area over 80 ha are handled by the Irrigation Department. At the scheme level, an Irrigation Engineer with the assistance of Technical Assistants and Work Supervisors handles the O\&M of the system.

Established in 1900 as a technical organization, the Irrigation Department has been paying greater attention to water management in recent times.

\subsubsection{Irrigation Management Division}

In 1984, the Government of Sri Lanka launched a program called the Integrated Management of Irrigation Schemes (INMAS) to improve coordination between the line agencies involved in irrigated agriculture. The Government also decided to recover a portion of the O\&M cost from the farmers (M/L\&LD 1984).

To facilitate this, the Irrigation Management Division (IMD) was formed under the Ministry of Lands and Land Development (M/L\&LD). This division operates with a multi-disciplinary staff. At the irrigation scheme level, the Division functions through a Project Manager. He normally chairs the Project Management Committee meetings, where farmer leaders and line agency officials meet. An Institutional Development Officer and Institutional Organizers help him in institutional development activities on some schemes.

Some of the responsibilities of the division are:

1. Allocation of funds for O\&M and improvement works in major irrigation schemes.

2. Establishment of farmer institutions in major irrigation schemes.

3. Monitoring the use of irrigation water and agriculture production activities.

4. Collection of O\&M fees from farmers (M/L\&LD 1984). ${ }^{1}$

\subsubsection{Mahaweli Authority of Sri Lanka}

The Mahaweli Authority is the coordinating body for the various agencies connected with the Mahaweli Program. These agencies handle construction, headwork maintenance, distribution of water to different schemes-including some which do not come under the Mahaweli Authority-and O\&M of irrigation schemes.

\footnotetext{
${ }^{1}$ This latter function has not been implemented during the past few years.
} 
result, this study will use the actual duration of the irrigation season as an index to measure the effect of some management interventions.

For land preparation, the officially estimated duration is 15 days. However, in most instances, farmers are unable to complete land preparation within this period, due to several constraints. So it is usual to allow 30 days for land preparation in most major schemes.

While many farmers grow long-term varieties in the maha season, short-term varieties are recommended for the yala season. Since the crop growth period for long-term varieties is 135 days and 105 days for short-term varieties, and assuming that the crops do not require water for the last 15 days of growth (Ponrajah 1981), the following norms can be calculated for this index:

Maha Season

$\begin{array}{ll}\text { Land preparation } & =15-30 \text { days } \\ \text { Crop growth } & =135 \text { days } \\ - \text { less } & =15 \text { days } \\ \text { Total } & =135 \text { to } 150 \text { days }\end{array}$

Yala Season

$\begin{array}{ll}\text { Land preparation } & =15-30 \text { days } \\ \text { Crop growth } & =105 \text { days } \\ - \text { less } & =15 \text { days } \\ \text { Total } & =105 \text { to } 120 \text { days }\end{array}$


Subsequently, the Vel Vidane System was established. The Vel Vidane was elected by the farmers and appointed by the authorities for a certain period. He was responsible for the supervision of the maintenance of irrigation canals, the distribution of water among the farmers, and the reporting of any breaches of irrigation regulations to the officers concerned (Abeyratne 1986). In the major schemes, his authority extended over the field channel system. For his services, the farmers had to pay him a portion of their production.

Under the INMAS Program and the subsequent Irrigation System Management Project (ISMP), the farmer organizations in the major schemes which came under those programs were institutionalized. The participatory management of irrigation systems was officially adopted as a government policy in 1988. In 1991, steps were initiated to hand over the management of the distributary canals to farmer organizations in the irrigation schemes coming under ISMP.

It is estimated that about 46 percent of the distributary canals are turned over to farmer organizations for O\&M. There is a general feeling among the farmers that water distribution within the areas controlled by them have improved, which is attributed to the planning and supervision of water delivery activities by the farmers themselves. However, observations made at Rajangane indicate that funds for maintenance activities are still being provided by the Government. Operations within the areas turned over are also being subsidized. Farmers continue to view the responsibility of repairs to concrete and masonry structures as the responsibility of the Irrigation Department (Gamaathige et al. 1995).

\subsection{COMMUNICATION BETWEEN ORGANIZATIONS}

The organization of the Mahaweli Economic Agency (MEA) comprises different disciplines such as engineering, agriculture and community welfare. Thus, coordination between different disciplines is included in the structure. Matters related to cultivation are discussed at meetings with farmer groups organized by the MEA staff (Jayawardane and Jayasingha 1990).

Outside the Mahaweli Project area, the Government Agent has, until recently, been the key person to coordinate activities of the line agencies engaged in the irrigation sector of an administrative district. Matters related are discussed at the District Agricultural Committee (DAC) which meets once a month.

Before each cultivation season, a cultivation meeting (kanne meeting) is held for an irrigation scheme. It is chaired by the Government Agent and is attended by the respective officers of the line agencies, and all the farmers of the irrigation scheme. The main purpose of this meeting is to fix the dates for the season such as first and last dates of water issue, dates to complete canal clearing, etc. But related matters such as availability of seed paddy and crop insurance are also discussed.

Under the INMAS Program mentioned above, the field staff activities at the project level are coordinated at the Project Management Committee. This provides a better opportunity for communication since only the project level, and irrigated agriculture related matters are discussed at a 
The Mahaweli Economic Agency is responsibje for the agricultural, social, and economic development in areas coming under the Mahaweli Program. The organization of each project is headed by a Resident Project Manager. His staff comprises a Land Officer, a Water Management Engineer, a Marketing Officer, an Agricultural Officer, a Community Development Officer, an Accountant and an Administrative Officer. The project is subdivided into several blocks and each block is managed by a Block Manager. A block is further divided into units, managed by a Unit Manager assisted by a Field Assistant (Bandaragoda 1986).

The authors expected to include a Mahaweli System in the present study, but had to drop this idea for technical reasons.

\subsubsection{Other State Organizations}

Other state organizations involved with agriculture include the Agriculture Department; the Agrarian Services Department, the Land Commissioners Department, the Agricultural Development Authority, the Paddy Marketing Board, the Agricultural Insurance Board, state banks, the Department of Co-Operatives, and the Department of Rural Development.

\subsection{FARMER ORGANIZATIONS}

The history of Sri Lanka's irrigation provides evidence of the existence of farmer participation in irrigation activities from ancient times. Two distinct features of the ancient irrigation system were the small village tank and the large storage reservoir. The macro-irrigation eco-system based on the large storage reservoir contained one or more micro-irrigation eco-systems based on village tanks or river diversions, or both (Mendis 1989). There is evidence that major irrigation systems developed around major cities. Two main functions of this hydraulic system were to provide the city with water and provide the area around the city with a source of reliable irrigation supply. The management of small tanks located in the villages was the responsibility of the villagers. As a result, even during political upheavals which disrupted the functioning of the government and the maintenance of the major works, the village irrigation systems were sustained. Historical documentary sources credit monarchs with constructing and repairing parts of the irrigation system. However, there is no evidence to support the theory that the entire system was centrally controlled or managed (Leach 1959). Hence, it safe to assume that the management of the ancient irrigation system was shared between the beneficiaries and the state.

After the collapse of the hydraulic civilization in the Dry Zone, the first major attempts to restore the collapsed irrigation systems were made by the British. They wanted to increase the food production of the country by improving irrigation in order to reduce the cost of food imports and to stem social unrest to a certain extent. But they also wanted to be least involved in village level irrigation management. Under the policy they adopted, the Government financed a part of the rehabilitation cost while the Gamsabhava, or the Village Council became responsible for the management of the village irrigation system. The Irrigation Ordinance of 1856 gave legal recognition to this process. Sometime later, the Village Headman was also incorporated into the system (Abeyratne 1986). 
This is an ancient scheme, which was restored in 1951. After restoration, farm families were resettled and allocated 2 ha for farming and 1.2 ha for homestead and highland farming. The deterioration of the physical system resulted in rehabilitation in the early 1970s (IIMI 1992).

This scheme came under the INMAS Program in 1984. Growing nonrice crops was promoted here from the start of the scheme. In 1985, IIMI started a research program with the broad objective of identifying and developing strategies to facilitate more intensive diversified cropping (IIMI 1992). This is reputed to be a scheme affected by water shortages.

\subsubsection{Mapakada Scheme}

This irrigation scheme is located in the Badulla District in the Uva Province. This is also an ancient scheme, which was restored in 1952-53 (Arumugam 1969). As shown in Table 5 , this is the smallest scheme selected for the study having a catchment area of about $7 \mathrm{sq.km}$ (square kilometers) and a capacity of 8.3 MCM (million cubic meters). The designed command area under the scheme is 376 ha. However, this has now expanded 46 percent to 548 ha.

This scheme came under the INMAS Program in 1984. The infrastructure was improved under the Badulla District Integrated Rural Development Program from 1983 to 1989 . The improvements included rehabilitation of field channels and the provision of several farm lots with direct access to channels. The expansion of the command area is partly due to the rehabilitation (Palipana, Nihal. Personal communication. 1994).

\subsubsection{Parakrama Samudra Scheme}

The Parakrama Samudra Scheme (PSS) is located in the North Central Province which falls within the Dry Zone of Sri Lanka. Table 5 shows the catchment area as $73 \mathrm{sq} . \mathrm{km}$ and the capacity as $135 \mathrm{MCM}$. However, the main water source is the diverted inflow from Amban Ganga. At present, the inflow usually exceeds reservoir capacity in maha, and there are no serious water shortages in yala.

This scheme was originally built in the 12th century, by combining three existing smaller reservoirs and augmenting the supply by a diversion weir. Restoration of the irrigation system was completed between 1948 and 1952 by the Irrigation Department (Arumugam 1969). It was resettled with about 4,000 new farm families and each farmer was allocated approximately 2.5 ha of irrigable land and 1.2 ha of highland suitable for perennial crops and homestead. According to Table 5 , the originaily designed command area of 7,950 ha has increased 23 percent to about 9,800 ha.

The average annual rainfall is $1,470 \mathrm{~mm}$. The major part of the rain falls between October and March, during the northeastern monsoon. The population density of the area is 98 persons per ha (Department of Census and Statistics 1992).

The major crop grown in the scheme is rice. This scheme came under the INMAS Program in 1984 and it was improved under ISMP from 1987. 
limited gathering. In schemes where the Project Management Committee System exists, a "pre-kanna meeting" is held where important dates of an irrigation season are negotiated and agreed upon. ${ }^{2}$

For special irrigation projects and programs, national level steering committees or coordinating committees are established to coordinate the activities of the agencies.

\subsection{DESCRIPTION OF IRRIGATION SCHEMES}

\subsubsection{Basic Physical Characteristics of the Five Schemes}

Table 5 summarizes the basic physical characteristics of the five irrigation schemes.

Table 5. Basic physical characteristics of the five schemes.

\begin{tabular}{|c|c|c|c|c|c|}
\hline Scheme & $\begin{array}{l}\text { Catchment } \\
\text { area } \\
\text { (sq.km) }\end{array}$ & $\begin{array}{l}\text { Reservoir } \\
\text { capacity } \\
\text { (MCM) }\end{array}$ & $\begin{array}{c}\text { Designed } \\
\text { command } \\
\text { area } \\
\text { (ha) }\end{array}$ & $\begin{array}{l}\text { Present } \\
\text { estimated } \\
\text { command } \\
\text { area (ha) }\end{array}$ & $\begin{array}{l}\text { Percent } \\
\text { change }\end{array}$ \\
\hline Dewahuwa & 67 & 10.9 & 945 & 1,214 & 28 \\
\hline Mapakada & 7 & 8.3 & 376 & 548 & 46 \\
\hline Parakrama Samudra & 73 & 135.0 & 7,950 & $\because 9,800$ & 23 \\
\hline Rajangane & 1,611 & 101.0 & 5,370 & 5,600 & 4 \\
\hline Ridiyagama & 31 & 27.0 & 2,513 & 3,440 & 37 \\
\hline
\end{tabular}

Sources: Arumugam 1969.

Irrigation Department 1975.

ECL 1992.

O\&M of the five schemes are managed by the Irrigation Department. Farmer organizations and interagency coordination is handled by the Irrigation Management Division.

\subsubsection{Dewahuwa Scheme}

The Dewahuwa Scheme is located in the Matale District of the Central Province. Table 5 shows that the command area under the scheme has expanded 28 percent from the designed command area of 945 ha (Arumugam 1969) to 1,214 ha.

\footnotetext{
${ }^{2}$ The system described above is what was in operation for the period covered by the study. Recently, the responsibilities of the Government Agent have been devolved to the Divisional Secretary. More importantly, the Irrigation (Amendment) Act of 1994 has legalized the authority of the Project Management Committee, in essence replacing the cultivation meetings.
} 
3. Sub-Project Management Committee-This is established only in larger schemes. The purpose is to decentralize coordination activities. This is formed of representatives of DCOs and line agencies.

4. Project Management Committee-This is formed of representatives of the farmer organizations and officials of the line agencies.

In the Dewahuwa, Mapakada, Parakrama Samudra, Rajangane and Ridiyagama schemes which were selected for this study, the Project Management Committees are said to be functioning and active (Danansooriya, S. Personal communication. 1994).

\subsubsection{Irrigation System Management Project (ISMP)}

The ISMP commenced in 1986 with funds received from the United States Agency for International Development (USAID). The Project covers the four major irrigation systems in Polonnaruwa District of the North Central Province, Gal Oya Right Bank System, and an irrigation system in the North Western Province. The project implementation was through the Irrigation Management Division with the Irrigation Department handling the construction component.

The ISMP had wide ranging objectives which included farmer organization development, improvements to the physical system, financial management, training capacity enhancement, research, and promoting a monitoring evaluation and feedback system. Training for the Project and research activities in the form of Diagnostic Analysis Studies commenced in 1984. In the development of farmer organizations, the Institutional Organizer approach was adopted (Blank 1986). The Project further planned to hand over the distributary (secondary) level irrigation system to the farmer organization for management, and this program is underway now.

The Project had a heavy management orientation. As an indirect result, cost-effective construction methods such as rubble packing in place of retaining walls, and vertical mass concrete drop structures in place of reinforced inclined drops were introduced. Attempts were made to calibrate the irrigation structures instead of going for expensive flow measuring structures (Sakthivadivel and Merrey 1992). Apart from one study commissioned by $\mathrm{IIMI}$ and conducted by Engineering Consultants Limited (ECL 1992), substantial studies have not yet been done to draw conclusions on the performance of the project.

The handing over of irrigation systems to farmers for management started in 1991. Under the present system, a maintenance plan for the distributary canal is prepared by the farmer organization with the help of the Irrigation Department. Farmers' responsibilities include the maintenance of canals and canal roads inclusive of structures, in accordance with the plan. They are responsible for the security of the system and the resolution of conflicts among water users. Among the rights of farmer organizations are collecting fees, imposing sanctions against members, obtaining details of O\&M of the main system and requesting technical assistance from the Irrigation Department on repairs. 


\subsubsection{Rajangane Scheme}

This is a new irrigation scheme constructed in 1957. The command area spreads over the Anuradhapura District of the North Central Province and the Kurunegala District of the North Western Province. It has a catchment area of $1,611 \mathrm{sq} . \mathrm{km}$ and a capacity of $101 \mathrm{MCM}$ (Arumugam 1969). The water supply to the reservoir is augmented by drainage water from the lands irrigated by the Kalawewa Reservoir of Mahaweli System $H$. As shown by Table 5, the designed command area under the scheme has increased slightly from 5,370 ha to about 5,600 ha at present (ECL 1992). Water resources are sufficient to cultivate the full extent in both seasons.

This scheme came under the INMAS Program in 1984. This is one of the schemes remodeled under MIRP from 1985.

\subsubsection{Ridiyagama Scheme}

The Ridiyagama Scheme is located in the Hambantota District of the Southern Province. Table 5 shows that it has a catchment area of 31 sq. $\mathrm{km}$ and a capacity of $27 \mathrm{MCM}$. The water supply is augmented by diverted waters from the Walawe Ganga. This scheme also rarely experiences water shortages.

The scheme was constructed in 1923-28 (Arumugam 1969) and the designed command area is 2,513 ha. The present area under command is 3,440 ha, a 37 percent increase. This scheme was planned to be brought under the INMAS Program in 1984. However, the actual implementation of INMAS began in 1990.

\subsection{DESCRIPTION OF INTERVENTIONS}

\subsubsection{Integrated Management of Irrigation Systems (INMAS)}

Essentially, the objective of this program is to establish closer coordination among the inputs and services needed for agriculture, thereby increasing agricultural productivity. Special focus is on the use of irrigation water (ML\&LD 1984).

Under the INMAS Program and the subsequent ISMP, the farmer organizations in the major schemes which came under these programs were institutionalized. The organization structure presently being promoted by the INMAS Program is as follows:

1. Field Channel Group (FCG)-An association of farmers at the field channel level.

2. Distributary Canal Organization (DCO) - A formal organization of farmers served by one or more distributary channels. This is composed of representatives of FCGs. 


\section{Performance Evaluation}

\subsection{PERFORMANCE OF DEWAHUWA SCHEME}

\subsubsection{Performance Level and Changes}

The data set available from the Dewahuwa Scheme is discontinuous and had to be supplemented with other sources such as IIMI research records. The estimated level of performance using available data is summarized in Table 6 .

Table 6. Performance of Dewahuwa Scheme.

\begin{tabular}{|c|c|c|c|c|c|c|c|c|}
\hline \multirow[t]{2}{*}{$\begin{array}{c}\text { Performance } \\
\text { indicator/parameter }\end{array}$} & \multicolumn{2}{|c|}{$\begin{array}{c}\text { Average } \\
\text { (1984-1993) }\end{array}$} & \multicolumn{2}{|c|}{$\begin{array}{c}\text { Past } \\
\text { performance } \\
\text { (1984-1987) }\end{array}$} & \multicolumn{2}{|c|}{$\begin{array}{c}\text { Present } \\
\text { performance } \\
(1991-1993)\end{array}$} & \multicolumn{2}{|c|}{$\begin{array}{l}\text { Percent } \\
\text { change }\end{array}$} \\
\hline & Maha & Yala & Maha & Yala & Maha & Yala & Maha & Yala \\
\hline $\begin{array}{l}\text { AIUW (ha/MCM) } \\
\text { (itrigation only) }\end{array}$ & 58.5 & 83.8 & 64.8 & 94.3 & 52.3 & 73.2 & -19 & -22 \\
\hline $\begin{array}{l}\text { AlUW (ha/MCM) } \\
\text { (total water) }\end{array}$ & 41.1 & 74.4 & 39.9 & 82.1 & 42.3 & 66.0 & +6 & -20 \\
\hline Irrigation Intensity (\%) & 80 & 51 & 100 & 35 & 67 & 50 . & -33 & +43 \\
\hline Irrigation Duty (m) & 1.70 & 1.22 & 1.56 & 1.07 & 1.91 & 1.38 & +22 & -29 \\
\hline $\begin{array}{l}\text { Actual Duty/Design } \\
\text { Norm (\%) }\end{array}$ & 128 & 72 & 117 & 63 & 144 & 81 & & \\
\hline Relative Water Supply & 1.09 & $\cdot$ & 1.15 & - & 1.08 & - & -6 & - \\
\hline $\begin{array}{l}\text { Irrigation Water } \\
\text { Productivity (tons/MCM) }\end{array}$ & 289 & - & 325 & - & 262 & - & -20 & - \\
\hline $\begin{array}{l}\text { Total annual production } \\
\text { (tons) }\end{array}$ & 4,946 & - & 6,082 & - & 4,057 & - & -33 & $=$ \\
\hline $\begin{array}{l}\text { Cropping Intensity (\%) } \\
\text { (annual) }\end{array}$ & \multicolumn{2}{|c|}{116} & \multicolumn{2}{|c|}{137} & \multicolumn{2}{|c|}{$\because 117$} & \multicolumn{2}{|c|}{-15} \\
\hline $\begin{array}{l}\text { Land Productivity } \\
\text { (tons/ha) }\end{array}$ & \multicolumn{2}{|c|}{4.74} & \multicolumn{2}{|c|}{4.85} & & & \multicolumn{2}{|c|}{+3} \\
\hline
\end{tabular}

Note: $\quad$ AlUW $=$ Area Irrigated per Unit Water. 


\subsubsection{Integrated Rural Development Program (IRDP)}

The IRDP was initiated with World Bank assistance in 1976. Some of the other organizations involved (for various districts) were International Fund for Agricultural Development (IFAD), NORAD, the Government of the Netherlands and the Government of Japan.

The aims of the project were as follows:

1. Spread development to areas not benefitting from lead projects such as the Mahaweli Development Program, the Greater Colombo Economic Commission (GCEC), and urban development and housing programs.

2. Help achieve balanced regional development.

3. Widen economic opportunities and enhance living conditions of the rural masses.

A basic feature of the Program was to have different programs for different administrative districts, with scope and focus varying to suit the field conditions. In some districts the irrigation sector received the major attention. The Program provided funds to improve medium and minor irrigation schemes. The Program principles stressed the importance of the participation of the intended beneficiaries (Peoples Bank 1989).

\subsubsection{Major Irrigation Rehabilitation Project (MIRP)}

The MIRP was funded by the World Bank and was implemented through the Irrigation Management Division, while the Irrigation Department attended to the physical improvements. The work started in 1985 and concluded in June 1993. It was originally planned to rehabilitate seven major irrigation schemes in North Central and North Eastern provinces. However, due to unstable civil conditions, work in three of the schemes had to be abandoned.

The Project objective was to increase agricultural production through rehabilitation and improvement of infrastructure and development of institutional organizations. A new approach adopted in this Project was to select a "pilot area" from each scheme to test the proposed improvements (Abeysekara 1993).

During the implementation period, the project was affected by problems like nonavailability of canal system data (Abeysekara 1993). Impacts of the rehabilitation effort were studied by ECL, under contract from IIMI (ECL 1992). 
Table 7. Length of irrigation season.

\begin{tabular}{|c|c|c|c|c|c|c|c|}
\hline \multicolumn{2}{|c|}{ Average } & \multicolumn{2}{|c|}{ Past } & \multicolumn{2}{|c|}{ Present } & \multicolumn{2}{|c|}{ Recommended range } \\
\hline Maha & Yala & Maha & Yala & Maha & Yala & Maha & Yala \\
\hline 148 & 123 & 165 & 121 & 145 & 135 & $135-150$ & $105-120$ \\
\hline
\end{tabular}

The longer duration of the maha season in the past period is influenced by the 1986/87 maha season which spanned over 176 days. This was cultivated in two staggers. If this season is excluded, the value goes down to 147 days. A decrease in the length of maha seasons can be observed from the results. However, the length of yala seasons has increased by about 12 percent.

\subsubsection{Other Performance-Related Parameters}

Changes in the performance-related parameters of rainfall, OFC cultivated area and rice yield are shown in Tabie 8.

Table 8. Performance-related parameters.

\begin{tabular}{|c|c|c|c|c|c|c|c|c|}
\hline \multirow{2}{*}{$\begin{array}{c}\text { Performance- } \\
\text { related } \\
\text { parameter }\end{array}$} & \multicolumn{2}{|c|}{$\begin{array}{c}\text { Average } \\
(1984-93)\end{array}$} & \multicolumn{2}{|c|}{ Past performance } & \multicolumn{2}{|c|}{ Present performance } & \multicolumn{2}{|c|}{ Percent change } \\
\hline & Maha & Yala & Maha & Yala & Maha & Yala & Maha & Yala \\
\hline Rainfall (mm) & 696 & 141 & 946 & 161 & 446 & 120 & -53 & +25 \\
\hline $\begin{array}{l}\text { OFC cultivated } \\
\text { area }(\%)\end{array}$ & - & 78 & - & 100 & - & 100 & - & 0 \\
\hline $\begin{array}{l}\text { Rice yield } \\
\text { (tons/ha一rough } \\
\text { rice) }\end{array}$ & 4.96 & - & 4.85 & - & 4.99 & - & +3 & ‘ \\
\hline
\end{tabular}

Note: $\quad$ OFC $=$ Other Field Crops. 
The past performance was evaluated using the 1984/85, 1985/86 and 1986/87 maha and 1985, 1986, and 1987 yala seasons. The present performance was measured using data from 1991 to 1993. Because of the high percent of OFC cultivation in the yala season, Irrigation Water Productivity and Relative Water Supply are calculated for the maha season only.

The results show that the performance has decreased with respect to most of the indicators used. One exception is Irrigation Intensity in yala season which has increased by 43 percent. The highest Irrigation intensity in yala was 100 percent, which was recorded in 1988 . Irrigation Intensity in maha shows a decrease of 33 percent, with all three seasons in the past period recording an Irrigation intensity of 100 percent.

Annual Cropping Intensity has declined from 137 to 117 percent which corresponds with the decline of annual Irrigation Intensity from 135 to 117 percent. The highest Cropping Intensity recorded was 150 in $1985 / 86$ and $1991 / 92$.

The area irrigated per unit volume of irrigation water has decreased by 19 percent in maha and 22 percent in yala. The best performance with regard to this indicator was in 1984/85 maha and 1986 yala, where the values were $74 \mathrm{ha} / \mathrm{MCM}$ and $103 \mathrm{ha} / \mathrm{MCM}$, respectively.

The same indicator calculated using rainfall as an input has increased by 6 percent in maha but decreased by 20 percent in yala. The best performance with regard to this indicator was in $1991 / 92$ maha and 1986 yala, when the values were $43.4 \mathrm{ha} / \mathrm{MCM}$ and $91 \mathrm{ha} / \mathrm{MCM}$, respectively.

Irrigation Duty has increased by 22 percent during the maha seasons and by 29 percent in the yala

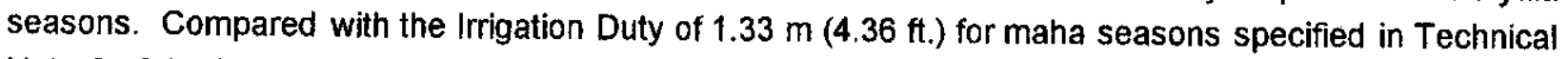
Note 6 of the Irrigation Department, the duty in this scheme is 28 percent higher than that specified for the maha seasons. In the yala seasons, the Irrigation Duty is 29 percent lower than the specified norm of $1.7 \mathrm{~m}$ (5.56 ft.).

Relative Water Supply (RWS) has decreased by 6 percent during maha seasons. This decrease has resulted in an improvement of performance considering 1 as the optimum value of RWS. According to the categorization adopted, present irrigation performance measured by RWS is of a good standard in the maha seasons. The optimum value recorded for RWS was 1.02 in 1991/92 maha.

The results show that Irrigation Water Productivity has decreased by 20 percent. The highest value of Irrigation Water Productivity was 373 tons/MCM in 1984/85 maha.

Average Land Productivity per season has increased by 3 percent from 4.85 tons per hectare (tons/ha) to 4.99 tons/ha. The highest value for this indicator was 5.27 tons per hectare per season (tons/ha/season) recorded in 1989/90.

Total annual production has decreased by 33 percent from 6,082 tons to 4,057 tons in the maha seasons. The highest production figure was recorded in 1985/86 maha when the value was 6,300 tons.

\subsubsection{Length of Irrigation Season}

In Dewahuwa Scheme, the maha season usually started between late September and early November. The only exception was maha 1989, which started in January 1989. In the yala seasons, the starting date was within the first half of May, except yala 1984 which started in June.

The behavior of the length of irrigation season is shown in Table 7. 


\subsection{PERFORMANCE of MAPAKADA SCHEME}

\subsubsection{Performance Level and Changes}

The estimated level of performance of the Mapakada Scheme using available data is summarized in Table 9.

Table 9. Performance of Mapakada Scheme.

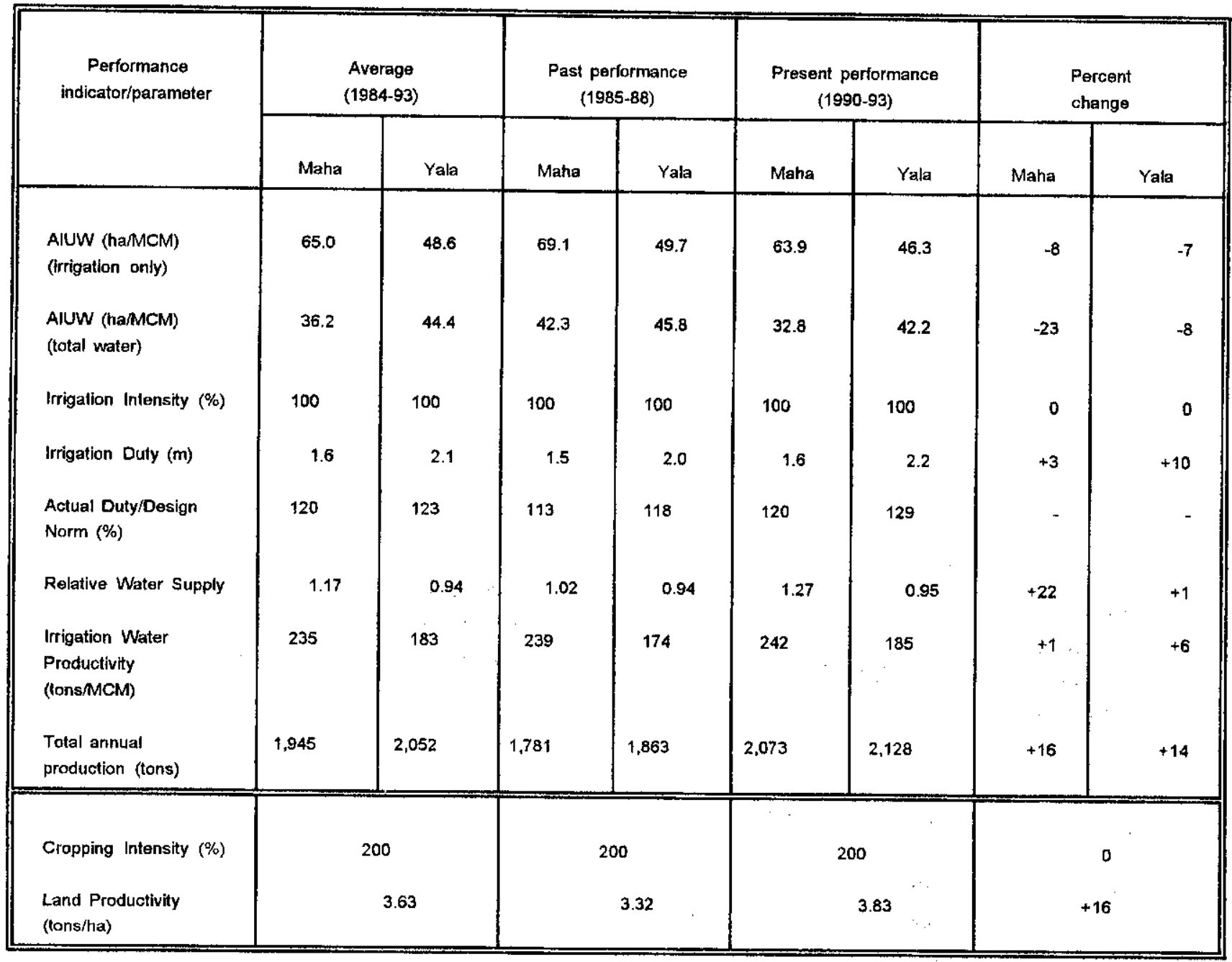

Note:

AlUW = Area Irrigated per Unit Water. 
Rainfall in the maha season has decreased by about 53 percent, while in the yala season it has decreased by 25 percent. OFC cultivated area has remained at approximately 100 percent according to IMD data. The average value is 78 percent because rice was cultivated in the yala seasons of 1988 and 1989. As noted above, rice yields have increased by 3 percent from 4.85 tons/ha to 4.99 tons/ha.

It should be noted that according to IIMI studies done from 1985 to 1987 , the rice cultivated area in yala varies between 8 and 20 percent. Hence, IMD data on OFC cultivated area seem to be approximate.

\subsubsection{Impacts and Inter-Relationships}

This scheme was included in the INMAS Program since 1984. Crop diversification was promoted in this scheme for a substantial period. This may have contributed to low Irrigation Duty in the yala season. Despite the increase in irrigation Duty, it can be seen that it is still below the design norm in the yala season.

The results show that irrigation performance has deteriorated with respect to most indicators, particularly in the yala season. The reductions in the length of the maha seasons are not reflected in the values for other performance indicators except in RWS.

Table 8 shows that rainfall in maha has decreased by 53 percent. This would partially explain the increase in Irrigation Duty and decrease in Area Irrigated per Unit Water which are inter-related, despite the decrease in the length of the maha seasons. The effect of the decrease of rainfall is further reflected in the decrease in RWS and increase in Area Irrigated per Unit Water with rainfall included, in the maha seasons. The low Irrigation Duty in the yala season is probably associated with the high percentage of OFC cultivation.

Although the Irrigation Intensity in yala has increased, the annual Irrigation Intensity has decreased from 135 to 117 percent. With the available data, it cannot be ascertained whether the increase in cultivated area in yala was at the expense of the maha cultivation. However, it is evident that the overall performance of the scheme has declined.

The results show that the total annual production has decreased over the period. Apparently, the decrease of the cultivated area in the maha seasons has prevailed over the slight increase in rice yield.

The decrease in Irrigation Water Productivity is due to the decrease of production and increased irrigation water use resulting from decreased rainfall in maha.

A major cause for the drop in performance in maha seems to be the decreased rainfall. This has probably contributed to higher irrigation releases. Although the length of the maha season has decreased, this was not sufficient to offset the ill-effects of reduced rainfall on performance. 
Table 10. Length of irrigation season.

\begin{tabular}{|c|c|c|c|c|c|c|c|}
\hline \multicolumn{2}{|c|}{ Average } & \multicolumn{2}{|c|}{ Past } & \multicolumn{2}{|c|}{ Present } & \multicolumn{2}{|c|}{ Recommended range } \\
\hline Maha & Yala & Maha & Yala & Maha & Yala & Maha & Yaia \\
\hline 153 & 140 & $15 \uparrow$ & 124 & 152 & 136 & $135-150$ & $105-120$ \\
\hline
\end{tabular}

The meda (intermediate) season of 1991 described above was not included in the calculations. The results do not show an appreciable change in the length of maha seasons. However, an increase in the length of yala seasons is evident.

\subsubsection{Other Performance-Related Parameters}

Changes in the performance-related parameters of rainfall, OFC cultivated area and rice yield are shown in Table 11.

Table 11. Performance-related parameters.

\begin{tabular}{|c|c|c|c|c|c|c|c|c|}
\hline \multirow{2}{*}{$\begin{array}{c}\text { Performance- } \\
\text { related } \\
\text { parameter }\end{array}$} & \multicolumn{2}{|c|}{$\begin{array}{l}\text { Average } \\
(198493)\end{array}$} & \multicolumn{2}{|c|}{$\begin{array}{l}\text { Past performance } \\
\text { (1985-88) }\end{array}$} & \multicolumn{2}{|c|}{$\begin{array}{l}\text { Present performance } \\
\qquad(1990-93)\end{array}$} & \multicolumn{2}{|c|}{$\begin{array}{l}\text { Percent } \\
\text { change }\end{array}$} \\
\hline & Maha & Yala & Maha & Yala & Maha & Yala & Maha & Yala \\
\hline Rainfall (mm) & 1,308 & 186 & 1,136 & 172 & 1,448 & 201 & +27 & +17 \\
\hline $\begin{array}{l}\text { OFC cultivated } \\
\text { area }(\%)\end{array}$ & - & 5 & - & 1.76 & - & 8.26 & $\therefore \quad-$ & +400 \\
\hline $\begin{array}{l}\text { Rice yield } \\
\text { (tons/ha-rough } \\
\text { rice) }\end{array}$ & 3.55 & 3.74 & 3.25 & 3.40 & 3.78 & 3.88 & +16 & +14 \\
\hline
\end{tabular}


The past performance was evaluated using the $1985 / 86,1987 / 88$ and the $1988 / 89$ maha seasons and 1985,1987 , and 1988 yala seasons. The present performance was measured using data from the $1990 / 91$ to $1992 / 93$ maha seasons and the 1990, 1992 and 1993 yala seasons.

The area irrigated per unit volume of irrigation water has decreased by 8 percent in maha and 7 percent in yala. The best performance with regard to this indicator was in 1987/88 maha and 1989 yala, where the values were $83 \mathrm{ha} / \mathrm{MCM}$ and $52 \mathrm{ha} / \mathrm{MCM}$, respectively.

The same indicator calculated using rainfall as an input has decreased by 23 percent in maha and increased by 8 percent in yala. The best performance with regard to this indicator was in $1987 / 88$ maha and 1989 yala, where the values were $61 \mathrm{ha} / \mathrm{MCM}$ and $47 \mathrm{ha} / \mathrm{MCM}$, respectively.

Irrigation Intensity in both seasons has remained at 100 percent. Cropping Intensity has also remained constant at 200 percent.

Irrigation Duty has increased by 3 percent during maha seasons and by 10 percent in yala seasons. Compared with the average Irrigation Duty of $1.33 \mathrm{~m}(4.36 \mathrm{ft}$.) for maha seasons specified in Technical Note 6 of the Irrigation Department, the duty in this scheme is 20 percent higher than that specified for maha seasons. In yala seasons, the Irrigation Duty is 29 percent higher than the specified value of 1.7 m (5.56 ft.).

Relative Water Supply (RWS) has increased by 22 percent during maha seasons, and by 1 percent in yala seasons. The increase in maha has resulted in a decrease in performance considering 1 as the optimum value of RWS. According to the categorization adopted, present irrigation performance measured by RWS is of a poor standard in maha seasons, but of a good standard in yala seasons. The optimum values for RWS were 0.99 in 1984/85 maha and 0.96 in 1987 yala.

Irrigation Water Productivity has increased by 1 percent in maha, and by 6 percent in yala. The best values for Irrigation Water Productivity were 291 tons/MCM in 1992/93 maha and 203 tons/MCM in 1989 yala.

Land Productivity has increased by 16 percent over the period. The best achievement with regard to this indicator was 4.03 tons/ha, which was recorded in 1992/93.

The total annual production has increased by 16 percent in maha seasons and by 14 percent in yala seasons. The best values for production were 2,192 tons in 1992/93 maha seasons, and 2,219 tons in 1993 yala.

\subsubsection{Length of Irrigation Season}

The start of the maha season in Mapakada Scheme has varied between early October to mid-November. The recent maha seasons have started in early October to mid-October. The yala seasons have started between late March and late April.

A meda (intermediate) season was cultivated in 1991. OFCs were planned to be grown in 81 ha. Although the planned duration was 122 days, the season lasted for 202 days, from 10 March to 28 September 1991.

The behavior of the length of irrigation season is shown in Table 10. 
12. Performance of Parakrama Samudra Scheme.

\begin{tabular}{|c|c|c|c|c|c|c|c|c|}
\hline \multirow{2}{*}{$\begin{array}{l}\text { Performance } \\
\text { indicator/ } \\
\text { parameter }\end{array}$} & \multicolumn{2}{|c|}{$\begin{array}{l}\text { Average } \\
\text { (1984-93) }\end{array}$} & \multicolumn{2}{|c|}{$\begin{array}{l}\text { Past performance } \\
(1984-87)\end{array}$} & \multicolumn{2}{|c|}{$\begin{array}{l}\text { Present performance } \\
\qquad(1990-93)\end{array}$} & \multicolumn{2}{|c|}{$\begin{array}{l}\text { Percent } \\
\text { change }\end{array}$} \\
\hline & Maha & Yala & Maha & Yala & Maha & Yala & Maha & Yala: \\
\hline $\begin{array}{l}\text { AlUW (ha/MCM) } \\
\text { (irrigation only) }\end{array}$ & 73.4 & 65.7 & 76.3 & 61.7 & 70.4 & 67.3 & .8 & +9 \\
\hline $\begin{array}{l}\text { AlUW (ha/MCM) } \\
\text { (total water) }\end{array}$ & 47.2 & 56.6 & 46.5 & 57.6 & 45.4 & 59.3 & -2 & +3 \\
\hline $\begin{array}{l}\text { Irrigation Intensity } \\
(\%)\end{array}$ & 100 & 100 & 100 & 100 & 100 & 100 & 0 & 0 \\
\hline Irrigation Duty (m) & 1.37 & 1.53 & 1.32 & 1.62 & 1.43 & 1.5 & +8 & -7 \\
\hline $\begin{array}{l}\text { Actual Duty/Design } \\
\text { Norm (\%) }\end{array}$ & 103 & 90 & 99 & 95 & 108 & $\begin{array}{r}88 \\
\quad:\end{array}$ & $\therefore$ & - \\
\hline $\begin{array}{l}\text { Relative Waler } \\
\text { Supply }\end{array}$ & 0.85 & 1.05 & 0.79 & 1.06 & 0.85 & 1.07 & +8 & +1 \\
\hline $\begin{array}{l}\text { Irrigation Water } \\
\text { Productivity } \\
\text { (tons } M C M \text { ) }\end{array}$ & 350 & 256 & 376 & 249 & 308 & 273 & -18 & +9 \\
\hline $\begin{array}{l}\text { Total annual } \\
\text { production (tons) }\end{array}$ & 46,600 & 38,100 & 48,300 & 39,300 & 42,700 & 36,400 & -11 & -7 \\
\hline $\begin{array}{l}\text { Cropping Intensity } \\
\text { (annual) (\%) }\end{array}$ & \multicolumn{2}{|c|}{201} & \multicolumn{2}{|c|}{201} & \multicolumn{2}{|c|}{$203^{\prime}$} & \multicolumn{2}{|c|}{+2} \\
\hline $\begin{array}{l}\text { Land Productivity } \\
\text { (tons/ha) }\end{array}$ & & 4.47 & & 4.55 & & 4.26 & -6 & \\
\hline
\end{tabular}

Nofe: $\quad$ AlUW $=$ Area Irrigated per Unit Water. 


\subsubsection{Impacts and Inter-Relationships}

As mentioned earlier, this scheme was included in the INMAS Program from 1984, and the infrastructure was improved under IRDP. Although beneficiary participation at the implementation stage was envisaged under IRDP, studies show that this has not been very successful (Dayaratne 1991).

The rehabilitation under IRDP included improving and extending the field channels, and providing several farms with direct access to field channels. This must have improved the equity and reliability of the water supply. According to Irrigation Department estimates, the area with irrigation facilities increased by 46 percent from 376 ha to 548 ha immediately after rehabilitation. The actual irrigated area remained constant at 548 ha. It can be assumed that better water distribution has helped increase the productivity, though water use has also increased. The changes in length of the season correspond with the performance changes related to water supply, especially in the yala season.

The rainfall in the later period is higher than that in the earlier period. But, this has not resulted in a decrease in Irrigation Duty as expected. This indicates that rainfall utilization can be improved in the Mapakada Scheme. However, due to high water availability in the maha season and constraints due to tank capacity, motivation for high rainfall utilization is minimal. Because of the low and sporadic nature of rainfall in yala, it is preferable to compare the performance in yala without the effect of rainfall.

The results show substantial improvements in performance with respect to agricultural production related indicators. The rice yield has increased by 16 percent in maha and by 14 percent in yala. These increases can be linked to the increase in Land Productivity and the total production. The increase in Irrigation Water Productivity is dampened by the increase of water use, despite higher rainfall in the later period.

In summary, the results show that the performance can be improved by higher management effort. Reducing the length of the irrigation season and better utilizing rainfall can substantially increase the water supply performance.

\subsection{PERFORMANCE OF PARAKRAMA SAMUDRA SCHEME}

\subsubsection{Performance Level and Changes}

The estimated level of performance using available data is summarized in Table 12.

The past performance was evaluated using the $1984 / 85$ to $1986 / 87$ maha seasons and the 1984 to 1986 yala seasons. The present performance was measured using the data from 1990/91 to 1992/93 maha seasons and 1991 to 1993 yala seasons.

The area irrigated per unit volume of irrigation water has decreased by 8 percent in maha, but has increased by 9 percent in yala. The best performance with regard to this indicator was in 1985/86 maha and 1989 yala, when the values were $82 \mathrm{ha} / \mathrm{MCM}$ and $75 \mathrm{ha} / \mathrm{MCM}$, respectively.

The same indicator calculated using rainfall as an input has decreased by 2 percent in maha, but has increased by 3 percent in yala. The best performance with regard to this indicator was in 1987/88 maha and 1992 yala, when the values were $63 \mathrm{ha} / \mathrm{MCM}$ and $66 \mathrm{ha} / \mathrm{MCM}$, respectively. 
Table 13. Length of irrigation season.

\begin{tabular}{||c|c|c|c|c|c|c|c|}
\hline \multicolumn{2}{|c|}{ Average } & \multicolumn{2}{|c|}{ Past } & \multicolumn{2}{c|}{ Present } & \multicolumn{2}{c|}{ Recommended range } \\
\hline Maha & Yala & Maha & Yala & Maha & Yala & Maha & Yala \\
\hline 142 & 135 & 148 & 143 & 145 & 134 & $135-150$ & $105-120$ \\
\hline
\end{tabular}

\subsubsection{Other Performance-Related Parameters}

Changes in the performance-related parameters of rainfall, OFC cultivated area and rice yield are shown in Table 14.

Table 14. Performance-related parameters.

\begin{tabular}{|l|c|c|c|c|c|c|c|}
\hline \multirow{2}{*}{$\begin{array}{c}\text { Performance- } \\
\text { related parameter }\end{array}$} & \multicolumn{2}{|c|}{$\begin{array}{c}\text { Average } \\
(1984-93)\end{array}$} & $\begin{array}{c}\text { Past performance } \\
(1984-87)\end{array}$ & $\begin{array}{c}\text { Present performance } \\
(1990-93)\end{array}$ & \multicolumn{2}{c|}{$\begin{array}{c}\text { Percent } \\
\text { change }\end{array}$} \\
\cline { 2 - 7 } & Maha & Yala & Maha & Yala & Maha & Yala & Maha \\
\hline $\begin{array}{l}\text { Rainfall } \\
\text { OFC cultivated } \\
\text { area (\%) }\end{array}$ & 800 & 242 & 864 & 115 & 804 & 201 & -7 \\
$\begin{array}{l}\text { Rice yield } \\
\text { (tons/ha-rough } \\
\text { rice) }\end{array}$
\end{tabular}

The rainfall decreased by 7 percent in maha, but increased by 7 percent in yala. OFC cultivated area seems to be insignificant in both seasons but shows an upward trend. Rice yield has decreased in both seasons.

\subsubsection{Impacts and Inter-Relationships}

Water availability in this scheme is good. Usually; the tank spills during the maha season and reaches the full supply level at the beginning of yala, so there is little motivation to improve water use in maha. 